\title{
El cumplimiento específico de los contratos de servicio en el derecho español: perspectivas sustantiva y procesal
}

\section{Gonzalo Severin Fuster ${ }^{* *}$}

Resumen: Este trabajo pretende analizar, en el derecho español vigente, en qué medida es posible afirmar que, tratándose de contratos de servicios, el cliente tiene derecho a obtener el cumplimiento específico en caso de incumplimiento contractual. Debido a la existencia de un derecho al cumplimiento específico o in natura, y por su carácter "preferente", este remedio puede -y debe- analizarse desde dos perspectivas que, si bien son complementarias, son diferentes. Una es la perspectiva sustantiva y la otra es la perspectiva procesal. Este trabajo aborda y desarrolla ambas perspectivas.

Palabras clave: Incumplimiento, cumplimiento específico, ejecución, contratos de servicio, obligaciones de hacer.

Este trabajo corresponde a una adaptación del noveno capítulo de la tesis doctoral inédita titulada: Los contratos de servicio: la construcción histórica de la categoría y el derecho del cliente al cumplimiento específico (Madrid, 20I4) realizada bajo la dirección de la profesora Dra. Nieves Fenoy Picón, a quien agradezco los comentarios y las sugerencias realizadas en su oportunidad. Los errores son, desde luego, de mi exclusiva responsabilidad.

Fecha de recepción: I. ${ }^{\circ}$ de febrero de 2016 . Fecha de aceptación: I 8 de abril de 2016.

Para citar el artículo: G. Severin Fuster, "El cumplimiento específico de los contratos de servicio en el derecho español: perspectivas sustantiva y procesal", Revista de Derecho Privado, Universidad Externado de Colombia, n. ${ }^{\circ}$ 30, enero-junio de 20 I6, I 7 I-2 I 9 . DOI: http://dx.doi. org/I0.1860I/oI 234366.n30.07

* Doctor en Derecho por la Universidad Autónoma de Madrid, Madrid, España. Profesor de Derecho Civil de la Facultad de Derecho de la Pontificia Universidad Católica de Valparaíso, Valparaíso, Chile. Contacto: gonzalo.severin@ucv.cl 


\section{Specific Performance of Service Contracts in Spanish Law: Substantial and Procedural Perspectives}

Aвstract: This paper analyzes to what extent it can be said that in the case of service contracts, the customer is entitled to specific performance in the case of a breach of contract under current Spanish law. Due to the existence of a right to specific or in natura performance and because of its "preferred" character, this remedy can -and should- be analyzed from two complementary, although differing perspectives: one is the substantive perspective and the other is the procedural perspective. This work addresses and develops both perspectives.

KEYwords: Breach of contract, specific performance, Spanish Law, service contracts, obligations of duty.

Sumario: Introducción. I. La perspectiva sustantiva: el derecho del acreedor a obtener una condena al cumplimiento específico. A. La idea de que el acreedor tiene derecho al cumplimiento específico, y que este es el remedio "preferente". B. El cumplimiento específico en las obligaciones de hacer: el artículo rog8 c.c. II. La perspectiva procesal. El derecho a la ejecución in natura y la idea de que esta es la vía preferente de ejecución. A. El derecho a que la sentencia se ejecute "en sus propios términos". Su reconocimiento y sus límites. B. La ejecución específica de las condenas que imponen una obligación de hacer. Conclusiones. Bibliografía.

\section{Introducción}

[I] La forma en la que la doctrina civil española aborda en general el estudio del cumplimiento específico, como remedio frente al incumplimiento contractual ${ }^{\mathrm{I}}$, se caracteriza por una remisión al derecho procesal, remisión que parece partir de la base de que existe una relación de complementariedad necesaria entre lo dispuesto en los artículos ro94 y siguientes del Código Civil español (en adelante, c.c.) y la regulación contenida en la Ley de Enjuiciamiento Civil de 2000 (en adelante, LEC) sobre ejecución forzosa (Libro III, arts. 5 I 7 ss.) ${ }^{2}$.

I La doctrina civil española aborda este tema bajo diversas denominaciones: "pretensión de cumplimiento", "cumplimiento forzoso", "cumplimiento in natura", "ejecución forzosa". Sobre estas diferentes denominaciones y su alcance, véase, por ejemplo, Verdera Server, El cumplimiento forzoso de las obligaciones, Bolonia, Publicaciones del Real Colegio de España, I995, 2 I ss.

2 Es sintomático el que L. Díez-Picazo, en sus Fundamentos II, dedique menos de tres páginas al cumplimiento forzoso de la obligación, y que en ellas básicamente reproduzca las normas de la LEC 2000 (777-779). Vale la pena citar sus palabras en este punto: "En toda obligación existen como indispensables elementos el débito y la responsabilidad, que es la situación de sumisión [del patrimonio del deudor] al poder coactivo del acreedor, con el fin de que aquél logre la satisfacción de su interés en la obligación. En las sociedades organizadas, este poder coactivo 
[2] Esa remisión o referencia al derecho procesal es también la forma en la que suele abordarse el estudio del cumplimiento específico de las obligaciones de hacer, tanto en los textos generales ${ }^{3}$ como en los -por cierto relativamente escasos- trabajos referidos específicamente al cumplimiento específico de esa clase de obligaciones ${ }^{4}$. A modo de ilustración de lo que se acaba de decir, considéren-

tiene que realizarse judicialmente y a través de un procedimiento, que es el proceso de ejecución $[\ldots][E] l$ estudio pormenorizado de esta materia corresponde al Derecho procesal [...] [L] as reglas centrales en esta materia se encuentran contenidas en los arts. I094-I099 c.c. y en los preceptos de la Ley de Enjuiciamiento Civil, relativos a la ejecución, arts. 5 I 7 ss." (Díez-Picazo y PonCe DE León, L., Fundamentos del Derecho civil patrimonial, Madrid, Civitas, t. II, "Las relaciones obligatorias", 6. ${ }^{a}$ ed., 2008, 777-778; cursivas añadidas). En términos similares, por ejemplo, De PabLo Contreras: "[c]uando el deudor no quiere o no puede cumplir con su deber de prestación, el ordenamiento concede al acreedor los pertinentes remedios, encaminados a que aquélla, pese a todo, ingrese en su patrimonio (in natura o, en otro caso, mediante el pago de su equivalente en dinero). A tal fin, el Derecho procesal previene los oportunos mecanismos de ejecución forzada de la prestación (arts. 5 I 7 ss. Lec)" (en Martínez de Aguirre (coord.), Curso de Derecho civil iI, Derecho de Obligaciones, $3{ }^{a}$ ed., Madrid, Colex, 20 I I, Cap. 5, I87; cursivas añadidas). Y también en un sentido parecido, Esteban de la Rosa y Gómez Valenzuela, quienes explican: "[l]a acción de cumplimiento persigue que la parte, que ha incumplido la obligación, proporcione una solución al acreedor, a ser posible, con la misma prestación objeto de la obligación, que puede tratarse de dar, hacer o no hacer. De ahí que su concreto tratamiento en el derecho de obligaciones sea el de pretensión de cumplimiento. Y que, por ello, su regulación se encuentre (en el Derecho español, así como en otros sistemas jurídicos) a caballo entre la normativa sustantiva (c.c.) y procesal (LEC)" (Esteban De la Rosa, G. y Gómez Valenzuela, E., "La acción de cumplimiento específico en la contratación internacional", en SÁnchez Lorenzo, S. (coord.), Derecho contractual comparado: una perspectiva europea y transnacional, Navarra, Civitas, 20I3, I 598; cursivas añadidas). Cabe destacar que esta remisión es recíproca: también la doctrina procesal suele remitirse, al tratar las reglas de ejecución de las sentencias, a las mentadas normas del Código Civil. Ello se explica, en parte, porque las reglas procedimentales descansan sobre una serie de categorías cuya elaboración corresponde a la doctrina civilista (cfr. Verdera SERVER, ob. cit., 24-25). La principal de esas categorías es la distinción entre hacer personalísimo y no personalísimo (sobre el punto vuelvo más adelante).

Por otro lado, cabe destacar que la idea de que las reglas del Código Civil deben complementarse con las de la LEC no es una idea que se restringa al remedio del cumplimento específico, sino que se extiende a todo el sistema de remedios frente al incumplimiento. En este sentido se ha dicho, por ejemplo, que las bases normativas de todos los remedios frente al incumplimiento "están desperdigadas por el c.c. y por la Leciv, sin que obedezcan a una lógica interna, por lo que el sistema debe reconstruirse por el intérprete": Carrasco Perera, Á., Derecho de contratos, Aranzadi, 2010, 1047.

3 Ya entre los primeros comentaristas del Código Civil, y a modo de ejemplo, Scaevola, Comentarios del Código Civil, t. I9, 43 I-432 (en el comentario del art. 1098). También se refiere a las normas procesales Martín Pérez, A., "Comentario del artículo io98”, en Albadalejo, M. (dir.), Comentarios al Código Civil y compilaciones forales, Madrid, Edersa, I978, t. I 5, v. I, p. 332; y más recientemente, por ejemplo, Santos Briz, J., "Comentario del artículo iog8”, en Sierra Gil de la Cuesta, I. (coord.), Comentario del Código Civil, 2. . ed., Bosch, Barcelona, 2006, t. 6, I 23 - I28; y Verdera Server, R., “Comentario del artículo iog8”, en Cañizares, A.; De Pablo, P.; OrduÑa, J. y Valpuesta, R. (dirs.), Código Civil comentado, Navarra, Thomson-Civitas Aranzadi, 20 I I, v. 3, I 289-I 29r. Téngase presente que, por su fecha, la referencia en los dos primeros trabajos citados es al art. 924 LEC de I88 I; en los dos últimos, lo es a las normas de la LEC de 2000.

4 Así es como se aborda el tema del cumplimiento forzoso en el conocido trabajo de Moreno Quesada, B., "Problemática de las obligaciones de hacer", en RDP, n. ${ }^{\circ}$ 60, 1976, 470-502 (en lo que interesa, especialmente, pp. 494 ss.), trabajo que se considera pieza clave para el estudio de 
se las palabras introductorias de Domínguez Luelmo, en un trabajo titulado, precisamente, "Incumplimiento y ejecución forzosa en forma específica de las obligaciones de hacer" (2006):

La finalidad principal de esta colaboración es poner de relieve la insoslayable necesidad de acudir a las reglas previstas en la Ley de enjuiciamiento civil para que el acreedor pueda exigir el cumplimiento del deudor, obteniendo previamente una Sentencia de condena [...] [C]reo por ello que lo propio es utilizar la expresión 'ejecución forzosa' y enfocar la cuestión en términos procesales, cuestión que en ocasiones no parece tan clara a los ojos de los civilistas5.

[3] Así pues, da la impresión de que, a la hora de realizar un estudio sobre el remedio del cumplimiento específico de los contratos de servicios, resulta imprescindible tomar en consideración dos grupos de normas: las del Código Civil en

las obligaciones de hacer en el derecho español (en palabras de Álvarez VigaraY: "monografía [que] es, y continuará siendo durante bastantes años, el mejor trabajo sobre el tema, publicado en castellano" -en el Prólogo del libro de Ledesma Martínez, M. ${ }^{a}$ J., Las obligaciones de hacer, Granada, Comares, I999, I3-). Es también el mismo enfoque que adopta Verdera Server en su ya citada monografía El cumplimiento forzoso. Al tratar el cumplimiento de las obligaciones de hacer no sólo se remite a las normas derecho procesal, sino que las estudia con cierta profundidad (de ello trata el Cap. Io, 27 I ss.). También adopta este enfoque Manrique de Lara Morales, J. "La ejecución forzosa de la obligación de hacer infungible", en ADC, n. ${ }^{\circ} 54,200$ I (3) I I65-I224; si bien en este trabajo el enfoque está puesto únicamente en la obligación de hacer infungible o personalísima (y además, considérese que una parte importante de su estudio es sobre derecho comparado, siendo la parte dedicada al derecho español relativamente pequeña). Conviene apuntar que todos estos trabajos son anteriores a la entrada en vigor de la LEC de 2000 , y por tanto, en ellos la referencia es a la LeC de I88I, principalmente a su art. 924 (aunque el trabajo de ManRiQue de LaRa (200I) contempla, al final, un addenda que da cuenta brevemente del sistema adoptado en la LEC de 2000). En los trabajos publicados tras la entrada en vigor de la LEC de 2000 , el enfoque es el mismo: se trata del remedio del cumplimiento específico de la obligación de hacer; o más ampliamente, de la obligación no dineraria, con la obligada referencia a la Lec. En efecto, este es el enfoque que adopta Domínguez Luelmo, "Incumplimiento y ejecución forzosa en forma específica de las obligaciones de hacer", en Llamas Ромво, E. (coord.), Estudios de derecho de obligaciones de obligaciones: homenaje al profesor Mariano Alonso Pérez, Madrid, La Ley, 2006, 557-586 (de lo que doy cuenta de inmediato en el cuerpo del texto, y en la nota siguiente). Es también el enfoque que adopta Morales Moreno, al tratar de la pretensión de cumplimiento y de la pretensión indemnizatoria. El autor dedica parte de dicho estudio a desentrañar la naturaleza de las medidas de ejecución de las obligaciones no dinerarias, analizando los artículos 699 ss. Lec de 2000 (La modernización del Derecho de Obligaciones, Navarra, Thomson-Civitas Aranzadi, 2006, 78 ss.). También se refiere a esas normas de la Lec de 2000 Fenoy Picón, a fin de analizar su relación con las reglas que, sobre el remedio del cumplimiento específico, contiene la Propuesta de Modernización del Código Civil en materia de obligaciones y contratos del año 2009, cuyo análisis es el objeto de estudio de su trabajo ("La modernización del régimen del incumplimiento del contrato: propuestas de la Comisión General de Codificación. Parte segunda: los remedios del incumplimiento", en $A D C$, n. $^{\circ} 64$, 20 I I (4) pp. I 533 ss.).

5 Domínguez Luelmo, ob. cit., 558 ; cursivas añadidas. Conviene apuntar que el autor, en realidad, sólo dedica una parte de su trabajo a justificar la necesidad de acudir a las normas procesales; en el resto del trabajo, lo que hace es analizar derechamente esas reglas de la LEC sobre ejecución de condenas. 
materia de naturaleza y efecto de las obligaciones (en particular, interesa el artículo rog 8 c.c., que es el único artículo que, dentro de esa regulación, se refiere a las obligaciones de hacer $)^{6}$; y las normas de la LEc en materia de ejecución de las obligaciones, en particular, las reglas sobre ejecución de obligaciones no dinerarias (arts. 699 ss. LEC) ${ }^{7}$.

La pregunta que surge es cómo han de relacionarse dichos grupos de normas, y en particular, si es razonable explicar el derecho sustantivo a través de la referencia necesaria al derecho procesal. En mi opinión, la respuesta es la siguiente: aun cuando puede predicarse cierta complementariedad entre las normas del Código Civil (en materia de efecto de las obligaciones) y las normas de la LEc (en materia de ejecución), la relación que existe entre ellas es mucho más limitada de lo que parece desprenderse a primera vista. A mi juicio, la forma en que se regulan los procedimientos de ejecución en la LEC puede, en el mejor de los casos, tener cierta incidencia a la bora de optar por el remedio de cumplimiento específico en caso de incumplimiento de una obligación de hacer. Pero, la regulación sobre ejecución de la LEC no determina ni tiene incidencia en la posibilidad de que el acreedor de un contrato de servicio obtenga que se condene al prestador del servicio al cumplimiento específico de la prestación incumplida.

Existen, creo, dos razones que permiten fundar esa afirmación. La primera razón es que, en caso de incumplimiento por parte del prestador del servicio, el cliente no puede directamente acceder a la ejecución. En efecto, en virtud de lo dispuesto en el art. 520 LEC $^{8}$, el cliente del servicio (acreedor de una obligación contractual de hacer) requiere, en todo caso, obtener previamente una sentencia de

6 Hay, desde luego, algunas otras normas en el Código Civil referidas a obligaciones de hacer, que están ubicadas en otros títulos del Libro Iv del Código Civil: el art. I I6 I, que dispone que el acreedor no puede ser compelido a recibir la prestación o el servicio de un tercero cuando la calidad y circunstancias de la persona del deudor se hubiesen tenido en cuenta al establecer la obligación; el art. i i66, que dispone que en las obligaciones de hacer no es posible sustituir el hecho por otro contra la voluntad del acreedor, y el art. I i 84, que dispone la extinción de la obligación de hacer en caso de que la prestación resulte física o legalmente imposible.

7 La regulación de la LEC adopta una distinción entre obligaciones dinerarias y obligaciones no dinerarias. En el contexto del objeto de este estudio -el derecho del cliente al cumplimiento específico en los contratos de servicio- interesa la regulación de las obligaciones no dinerarias. Sin perjuicio de volver sobre ello más adelante, conviene tener presente, desde ya, que la Lec contempla procedimientos de ejecución diferenciados, según se trate de condenas no dinerarias de dar, de hacer y de no hacer; y por tanto, no todas estas reglas son de interés en el marco de este trabajo.

8 Art. 520 LEC ("Acción ejecutiva basada en títulos no judiciales ni arbitrales"):

"I. Cuando se trate de los títulos ejecutivos previstos en los números $4 \cdot^{\circ}, 5 \cdot^{\circ}, 6 .^{\circ}$ y $7 .^{\circ}$ del apartado 2 del artículo 5 I 7, sólo podrá despacharse ejecución por cantidad determinada que exceda de 50.000 pesetas (300 euros):

"I. ${ }^{\circ}$ En dinero efectivo.

“ $2 .{ }^{\circ}$ En moneda extranjera convertible, siempre que la obligación de pago en la misma esté autorizada o resulte permitida legalmente.

" $3{ }^{\circ}$ En cosa o especie computable en dinero.

“2. El límite de cantidad señalado en el apartado anterior podrá obtenerse mediante la adición de varios títulos ejecutivos de los previstos en dicho apartado". 
condena (u otro título ejecutivo "asimilado" al judicial)9. La segunda razón deriva de lo anteriormente dicho, y es una razón de pura lógica: el que se condene al deudor al cumplimiento específico de la obligación contractual de hacer depende de ciertas circunstancias, principalmente, de que el cumplimiento sea todavía posible (sobre ello vuelvo un poco más adelante), y es evidente que la concurrencia de dichas circunstancias es algo que debe considerarse, en todo caso, al momento de dictar la sentencia de condena. Dicho de otro modo, la previsión que pueda hacer el juez de instancia en relación con la posibilidad de que una sentencia de condena al cumplimiento específico vaya a ser cumplida, o no, en sus propios términos, es irrelevante al momento de dictar sentencia ${ }^{\mathrm{IO}}$.

[4] En consideración de lo que se acaba de indicar, me parece que la pregunta por la existencia de un derecho al cumplimiento específico o in natura puede -y debe- analizarse desde dos perspectivas que, si bien son complementarias, son diferentes: una es la perspectiva sustantiva, otra es la perspectiva procesal. Desde la perspectiva sustantiva, la pregunta es: ¿puede el acreedor (cliente de un servicio) obtener que se condene al deudor a realizar la prestación en los términos pactados? Desde la perspectiva procesal, la pregunta es: ¿puede el acreedor (cliente de un servicio) obtener que esa eventual sentencia de condena sea cumplida en sus propios términos?

9 Cfr. Moreno Catena, V. La ejecución forzosa, t. 4 de Cortés Domínguez, V. y Moreno CateNA, V. (coords.), "La nueva Ley de enjuiciamiento civil", Madrid, Tecnos, 2000, I 23-I 24. No modifica esta afirmación el hecho de que la LEC contemple un procedimiento monitorio, que tiene por objeto, precisamente, facilitar el acceso a la fase ejecutiva (arts. 8 I 2 ss.). Ello, porque este procedimiento monitorio sólo cabe tratándose de obligaciones dinerarias (sobre el punto, véase Vegas Torres, J., "Ejecución forzosa y medidas cautelares en la nueva Ley de enjuiciamiento civil", en Icade, n. ${ }^{\circ}$ 50, mayo-agosto, 2000 , I 45 ss.). Sobre los títulos de acceso a la fase de ejecución, enumerados en el art. 5 I 7 LEc, véase, en general, Moreno Catena, V. La ejecución forzosa, ob. cit., 63-78; y en particular sobre la mentada diferencia que existe entre la ejecución de obligaciones dinerarias y las no dinerarias, véase, por ejemplo, Moreno Catena, V., "Algunos problemas de la ejecución forzosa", en AFDUAM, n. ${ }^{\circ}$ 5, 200 I, I9 I-I92; y Alonso RodríGuez, M. ${ }^{a}$ Á., "Ejecución. presupuestos y disposiciones generales. Ejecución provisional”, en E7, 2003 (I), 755 . Por último, y en vinculación con este punto, conviene destacar que, si bien la enumeración de los títulos ejecutivos del art. 5 I 7 en cita no se considera una enumeración taxativa, no se trata de un sistema abierto, sino que es un sistema de numerus clausus: la creación de títulos ejecutivos es decisión del legislador (cfr. Alonso Rodríguez (2003) 758-762; Ortells Ramos, M., "La ejecución forzosa civil. Tres cuestiones sobre qué ejecutar, quién puede o debe hacerlo y cómo", en RDUM, n. ${ }^{\circ}$ 22, 2013 , IO9-I I 5). El contrato no es título ejecutivo, y tampoco las partes pueden darle este carácter (cfr., p. ej., Fernández-Ballesteros López, M. Á., La ejecución forzosa y las medidas cautelares, Madrid, Irgium, 200 I, 72).

Io En este sentido, me parece evidente que la existencia de ciertas vías procesales de ejecución de las sentencias es un dato que el acreedor podría -y debería - tomar en cuenta a la hora de elegir, primero, si demanda o no demanda al deudor, y luego, si le conviene demandar o no el cumplimiento específico de la obligación incumplida. Pero, una vez que el acreedor elige demandar el cumplimiento específico, lo que eventualmente pueda ocurrir después de la sentencia lógicamente no puede ser considerado por el juez a la hora de pronunciarse sobre la pretensión del actor (sobre la incidencia de la imposibilidad de la ejecución de la obligación, según ella se produzca antes o después de la sentencia de condena, véase infra notas 68 y 69). 
Este trabajo pretende dar respuesta a esas dos interrogantes. En consecuencia, se divide en sendas partes.

\section{La perspectiva sustantiva: el derecho del acreedor a obtener una condena al cumplimiento específico}

\section{A. La idea de que el acreedor tiene derecho al cumplimiento específico, y que este es el remedio "preferente"}

\section{El cumplimiento específico como efecto de la obligación. La perspectiva tradicional}

[5] Como es sabido, la posibilidad de exigir el cumplimiento de la obligación se ha considerado tradicionalmente como un efecto de ella ${ }^{\mathrm{I}}$. Miradas las cosas desde este punto de vista, sostener que el acreedor tiene un "derecho al cumplimiento" no supone sino describir el carácter vinculante de toda obligación: la obligación, por su propia naturaleza, crea el correlativo derecho personal o crédito en el patrimonio del acreedor. Dicho de otro modo, predicar un "derecho al cumplimiento" es simplemente expresión de que el acreedor tiene derecho a obtener la satisfacción de su crédito. Ahora bien, ¿ cómo obtiene el acreedor la satisfacción de su crédito? La respuesta a esta pregunta se obtiene a partir de dos ideas básicas, presentes en la doctrina española, y que, por conocidas, expongo a continuación de manera muy sintética.

[6] La primera idea que interesa destacar es que se admite que el acreedor puede obtener la satisfacción de su crédito por dos vías: puede obtenerla in natura (cumplimiento específico), o bien puede obtenerla por vía sustitutiva, esto es, mediante una suma de dinero representativa del valor de la prestación ${ }^{\mathrm{I} 2}$.

Que esa vía sustitutiva deba ser considerada como una forma de cumplimiento ("por equivalente") o, en cambio, que deba considerársele como una partida más dentro de la indemnización de daños (y sujeta por tanto a su régimen) es

I I Y, de hecho, no solo como un efecto más, sino como su efecto cardinal; cfr., p. ej., CastáN Toвeñas, J., Derecho civil español, común y foral, t. 3, I 7. a ed., Madrid, Reus, 2009, 234-235; PaNtaleón Prieto, F., "El sistema de responsabilidad contractual (materiales para un debate)", en ADC, n. ${ }^{\circ}$ 44, I991, Io46; y Morales Moreno, A. M., "Claves de la modernización del Derecho de Contratos", en Consejo General del Notariado, Autonomía de la voluntad en el Derecho privado. Estudios en conmemoración del I 5 o aniversario de la Ley del Notariado, t. III-I, Wolters Kluwer, 201 2,406 .

I 2 En este sentido, "[1]a obligación lleva consigo la necesidad ineludible de su cumplimiento por el deudor; si éste no quiere o se resiste, el derecho del acreedor no por eso se aminora, antes bien, subsiste intacto para exigir la prestación en forma específica, o su justo equivalente": DE Diego y Gutiérrez, F. C., Instituciones de Derecho Civil Español, t. 2, nueva edición revisada y puesta al día por Alfonso De Cossio y Corral y Antonio Gullón Ballesteros, Madrid, i959, 26; cursivas añadidas. 


\section{tema discutido ${ }^{13}$. En todo caso, en el marco de este trabajo no interesa adentrarse en tal problema. Basta con tener claro que esa vía sustitutiva no es considerada}

I 3 La autonomía del cumplimiento por equivalente (esto es, el valor de la prestación, aestimatio rei) respecto de la indemnización de los daños y perjuicios, como vía de tutela del acreedor en caso de imposibilidad sobrevenida de la prestación, ha sido defendida en el derecho español, entre otros, por Llamas Pомвo en una monografía del año ig99 (Cumplimiento por equivalente y resarcimiento del daño al acreedor. Entre la 'estimatio rei' y el 'id quod interest', Madrid, Trivium, I999). El objetivo de esa monografía es, en palabras del propio autor, abordar "un problema teórico que no ha sido adecuadamente resuelto: la precisa delimitación entre el remedio que supone obtener el equivalente pecuniario de la prestación, y aquel otro que propende a la indemnización de daños y perjuicios" (13). Llamas Pомво muestra que en el Código Civil existen normas que parecen diferenciar ambas pretensiones, y otras que parecen tratarlas como una sola cosa, y que ni existe una tendencia clara en la jurisprudencia del Tribunal Supremo (48 ss.), ni la doctrina está conteste sobre el punto (59 ss., ofreciendo aquí una interesante síntesis sobre las diversas posiciones doctrinales en la doctrina española). El autor sostiene, desde el comienzo de su exposición que la solución de la autonomía del equivalente pecuniario le parece "mucho más rigurosa técnica y lógicamente" (2 I), y es esa la posición que justifica a lo largo de su trabajo. Para Llamas Poмвo, más allá de la discusión sobre si la ejecución por equivalente es cumplimiento o indemnización, "lo que [...] no debería discutirse en nuestro Derecho es que cuando dicha situación se produce [se refiere a la imposibilidad de la prestación] el acreedor tiene derecho a tal equivalente, sin necesidad de realizar el mismo esfuerzo probatorio que si reclamase la indemnización de daños al interés de indemnidad o de un perjuicio extracontractual" (io6). En contra de esta forma de ver las cosas, por ejemplo, Pantaleón Prieto, para quien conservar la idea de la perpetuatio obligationis, propia del procedimiento romano, no se justifica en la actualidad y que es -en sus palabras- un "artificio inútil" (ob. cit., IO2 I). También, en este sentido, se manifiesta Verdera Server, quien sugiere que el cumplimiento por equivalente es una forma de referirse a la indemnización de daños, y que la estimatio rei se rige por el mismo régimen que los demás "daños" (El cumplimiento forzoso, cit., 209 ss.). Y en un sentido parecido, Esteban de la Rosa y Gómez Valenzuela expresan: “[e]l cumplimiento por equivalente está comprendido evidentemente en esta genérica obligación [los autores se refieren a la obligación indemnizatoria, con base en el art. I I I c.c.]" (ob. cit., I607). Para una síntesis de los problemas que conlleva adoptar la tesis de la autonomía del cumplimiento por equivalente, véase, verbigracia, VAttier Fuenzalida, C. "Notas sobre el incumplimiento y la responsabilidad contractual", en Redur, 3, 2005, p. 6o; y también L. Díez-Picazo, Fundamentos II, 780. Que existe confusión sobre el punto se puede ilustrar, por ejemplo, si se observa el trabajo, relativamente reciente, de Ayllón Santiago, H., "Cumplimiento sensu stricto en contrato unilateral y en contrato bilateral”, en O'Callaghan Muñoz, X. (coord.), Cumplimiento e incumplimiento del contrato, Editorial Universitaria Ramón Areces, Madrid, 20 I 2 (aquí, el autor utiliza como expresiones sinónimas "cumplimiento por equivalente", "id quod interest" e "indemnización monetaria", para luego "precisar" que el cumplimiento por equivalente "no debe, aunque de ordinario se haga, equipararse a la indemnización de daños y perjuicios": 26-29). El Tribunal Supremo, en algunas sentencias, ha considerado el cumplimiento por equivalente como parte de la indemnización de daños (así, por ejemplo, se ha dicho que "el incumplimiento de la obligación de resultado que había contraído el médico en el contrato de obra, cuyo incumplimiento [es] imputable al mismo, produce la responsabilidad que consistirá, en el presente caso, en el cumplimiento por equivalencia, id quod interest que comprende la indemnización de los daños materiales [...] y de los daños morales": sts (Sala i. ${ }^{\text {a) }}$ ) de 28 de junio de r 999 (Roj 4583/r999), Ponente: Excmo. Sr. D. X. O'Callaghan Muñoz (FD $\left.2 .^{\circ}\right)$. Sin embargo, se ha afirmado que es posible observar una evolución en la doctrina del Tribunal Supremo, en el sentido de que se reconoce la autonomía del cumplimiento por equivalente como remedio, frente a la indemnización de daños. Así, Sánchez CAstro, quien da cuenta de dicha tendencia en las decisiones del Tribunal Supremo, mostrando cómo se ha pasado de considerar el cumplimiento por equivalente como una partida de la indemnización de daños, a hacerlo como un remedio autónomo; cuáles son los requisitos de este "remedio" y bajo cuáles criterios se determina el monto de ese equivalente (SÁNCHEZ 
como parte del remedio del cumplimiento específico, que es lo que aquí interesa abordar.

[7] La segunda idea clave es que el hecho de que la obligación se conciba tradicionalmente como un deber de prestación ha llevado a entender que de esas dos posibles vías de satisfacción, el cumplimiento especifico o in natura es -o al menos debería ser- la vía prioritaria o preferente de satisfacción del acreedor. Ello porque, desde la perspectiva tradicional, el derecho a exigir al deudor que cumpla la obligación en los términos pactados es el contenido del derecho de crédito. Y de abi que el único presupuesto de procedencia de este derecho al cumplimiento especifico o in natura sea el que la prestación pueda ejecutarse ${ }^{\mathrm{I}}$. Dicho de otra forma, el cumplimiento específico aparece como un derecho del acreedor que no reconoce más límite que el de la imposibilidad de la ejecución, límite este que se explica -desde la perspectiva tradicional- porque la imposibilidad acarrea la extinción de la obligación (y consecuencialmente, acarrea la extinción del derecho correlativo para exigir su cumplimiento) ${ }^{15}$.

Es posible considerar, como otro límite de la pretensión de cumplimiento, el que su ejercicio no sea contrario a las exigencias derivadas de la buena fe (arts. 7 y ${ }_{2} 58$ c.c. $)^{16}$. La buena fe juega así un rol "tutelar" del interés del deudor, en

Castro, J. D., "El cumplimiento por equivalente: ¿un modo de evitar los requisitos imprescindibles en toda pretensión indemnizatoria?", en $A D C$, n. $^{\circ} 63,2010(4), 1725$-1 787 ).

I4 En efecto, entiende la doctrina que, "no habiendo imposibilidad definitiva, nuestro Derecho trata primero de conseguir el cumplimiento in natura, aunque sea por la fuerza [...] [E]l acreedor, no cumpliendo exactamente el deudor, puede hacer valer su derecho a la prestación exacta de forma específica": Lacruz Berdejo, J. L. et al., Elementos de Derecho civil II. Derecho de obligaciones, v. 2, "Contratos y cuasicontratos. Delitos y cuasidelitos", 4 . $^{\text {a }}$ ed., revisada y puesta al día por Francisco Rivero Hernández, Madrid, Dikynson, 2009, i62. En el mismo sentido, Castán Tobeñas, Derecho civil, t. 3, 268; y más recientemente, Abella Rubio, J. M. a ",Efectos del incumplimiento", en O'Callaghan Muñoz, X. (coord.), Cumplimiento e incumplimiento del contrato, Madrid, Editorial Universitaria Ramón Areces, 20 I 2, 36 I.

I5 Marsal y Lauroba sintetizan esta idea con claridad: "[s]i la imposibilidad era anterior a la celebración del contrato, éste no llegó a existir por falta de objeto (arts. I 272; I460 del c.c.); si es sobrevenida y definitiva, la obligación se extingue, salvo que la prestación sea imputable al deudor o se haya producido una vez el deudor estuviera en mora solvendi (arts. I i 82 ; i i 84 del c.c.) pues en estos casos se perpetúa la obligación sustituyendo la conducta de imposible realización por su estimación pecuniaria" (Marsal Guillamet, J. y Lauroba Lacasa, M. ${ }^{a}$ E., "Algunos mecanismos de protección en caso de incumplimiento contractual en un futuro derecho europeo de contratos: cumplimiento específico e indemnización por daños y prejuicios", en Cabanillas, A (coord.), Estudios jurídicos en homenaje al profesor Luis Díez-Picazo, v. 2, Civitas, 2002, 246I). Esto lo dicen los autores al comparar la aproximación del Código Civil español con la de los PECL (este último texto contempla expresamente a la imposibilidad como un límite de la pretensión de cumplimiento).

I6 El art. 7 c.c. dispone: “I. Los derechos deberán ejercitarse conforme a las exigencias de la buena fe. "2. La ley no ampara el abuso del derecho o el ejercicio antisocial del mismo...".

Por su parte, el art. I $25^{8}$ c.c. dispone: "Los contratos se perfeccionan por el mero consentimiento, y desde entonces obligan, no sólo al cumplimiento de lo expresamente pactado, sino también a todas las consecuencias que, según su naturaleza, sean conformes a la buena fe, al uso y a la ley". Como explica Pantaleón Prieto, la buena fe es un límite que opera por vía de excepción: "el deudor podrá oponerse con éxito a esa pretensión [se refiere a la de cumplimiento] cuando, conforme a la buena fe [...] el cumplimiento en las condiciones pactadas no sea 
cuanto permite "no llevar [el] sacrificio [del deudor] en el cumplimiento más allá de lo razonable" ${ }^{7}$. Sin embargo, también es posible plantear que, más que un límite autónomo al remedio de cumplimiento específico, la buena fe opera, en realidad, como un criterio para determinar la existencia de la imposibilidad, noción esta que, de esta manera, se ensancha ${ }^{\mathrm{I} 8}$.

Pero, además de considerarse un derecho del acreedor, el cumplimiento específico se mira también como la vía preferente de satisfacción del acreedor en el sentido de que "se erige como un verdadero derecho del deudor, de manera que el acreedor no puede optar libremente por exigir el valor de la prestación, sea como aestimatio, sea como indemnización por vía de responsabilidad"I9. Dicho de otro modo, "cuando [la obligación] sea todavía posible, [el acreedor] ha de dirigir a ella su reclamación de modo principal y al equivalente de modo subsidiario" ${ }^{20}$.

exigible" (ob. cit., I046). Para este autor no es exigible el cumplimiento en los casos en los que concurran "los requisitos de la figura de la 'excesiva onerosidad de la prestación' [...] o cuando el ejercicio de la prestación de cumplimiento deba considerarse abusivo [...] porque el coste del cumplimiento resulte absolutamente desproporcionado con la utilidad que le proporcionaría al acreedor, en comparación con los otros posibles remedios" (ibíd.).

i 7 Jordano Fraga, F., "Las reglas generales de la responsabilidad contractual en el sistema del Código Civil español”, en $A D C, \mathrm{I} 985,325$.

i 8 En este sentido, puede decirse que "[s]e produce un ensanchamiento del hecho liberatorio, en tanto que, junto a la imposibilidad estricta de la prestación, vienen en consideración todos aquellos supuestos en que, con arreglo a una valoración de buena fe de las circunstancias del contrato, el esfuerzo requerido por el deudor para cumplir sobrepasaría el límite de lo exigible, de forma que la exigencia por el acreedor del cumplimiento en estos casos se califica como desleal, incorrecta o abusiva" (Jordano FragA, I985, 324). Miradas las cosas desde esta perspectiva, la "excesiva onerosidad de la prestación" o la "dificultad extraordinaria" son circunstancias que, si bien no son en sentido estricto supuestos de imposibilidad, pueden equipararse a la imposibilidad, y así lo ha sostenido el Tribunal Supremo. Para una clara síntesis de la doctrina del Tribunal Supremo en relación con este punto, véase la sTs (Sala I. ${ }^{a}$ ) de 30 de abril de 2002 (Roj 3 107/2002), Ponente: Excmo. Sr. D. J. Corbal Fernández (FD. 7. ${ }^{\circ}$ ). Por otro lado, admitir la posibilidad de revisión del contrato, en los casos en los que existe una alteración sustancial de las circunstancias (comparadas las circunstancias en las que se celebró el contrato con las que existen al momento de su cumplimiento; sobreentendiendo la cláusula rebus sic stantibus), supone admitir, indirectamente, un límite a la pretensión de cumplimiento del acreedor, aunque no se diga en esos términos. Sobre la admisibilidad en el derecho español de la cláusula rebus sic stantibus, pese a su falta de reconocimiento legal, se pronunció, por ejemplo, la conocida sTs (Sala I. ${ }^{a}$ ) de I 7 de mayo de 1957 (Repertorio de jurisprudencia I957/2 I64), Ponente: Excmo. Sr. D. F. Eyré Varela (véase el cdo. $5 \cdot^{\circ}$ ).

I9 Llamas Ромвo, El cumplimiento, cit., 230; cursivas añadidas. En este mismo sentido, Verdera SERVER, El cumplimiento forzoso, cit., I 34 ss.

20 Lacruz Berdejo et al., Elementos, cit., i62. Así, “[n]o siendo viable el cumplimiento in natura, sea por imposibilidad de prestar o por voluntad del deudor, el c.c. en unos casos extingue la obligación, y en otros la transforma en la de entregar un equivalente pecuniario de la prestación fallida: su precio o valor, que no se separa con nitidez de la indemnización de daños" (ibíd., i63). Ahora bien, lógicamente esto no quiere decir que el acreedor no pueda, en caso de incumplimiento del deudor en un contrato bilateral, optar por la resolución del contrato y pedir, junto con ello, una indemnización de daños. 


\section{El cumplimiento específico como remedio frente al incumplimiento contractual. La perspectiva moderna}

[8] Las ideas antes expuestas expresan, sintéticamente, la aproximación tradicional: el cumplimiento específico es un derecho del acreedor, y es la vía preferente de satisfacción de su crédito. Ahora bien, ¿̇tales ideas describen adecuadamente la aproximación de la doctrina más moderna, aquella que se hace desde el denominado "Nuevo derecho de la contratación"? ${ }^{2}$.

Para responder a la pregunta, lo primero que hay que tener en cuenta es que, desde esa perspectiva moderna, la pretensión de cumplimiento ya no se considera -al menos ya no únicamente- como un "efecto de la obligación", sino que se le mira como un remedio frente al incumplimiento contractual. Un remedio que se inserta en un catálogo más amplio de remedios por el incumplimiento contractual, y que están a disposición de la parte cumplidora dispuesta a cumplir. En este esquema, cada uno de esos remedios tiene sus propios presupuestos, objetivos y límites ${ }^{22}$.

Si bien existe cierto consenso en la doctrina moderna en utilizar la expresión "remedios" para referirse al elenco de derechos del acreedor en caso de incumplimiento, no parece posible afirmar que exista consenso a la bora de enumerar $y$ describir cuáles son esos remedios por incumplimiento. En todo caso, lo anterior no representa un problema en relación con el objeto de estudio de este trabajo, pues la "pretensión" o la "acción" de cumplimiento ("forzoso" o "en forma específica”) aparece siempre enumerada dentro de ese catálogo de remedios por incumplimiento que los distintos autores identifican ${ }^{2} 3$.

2 I Ese es el nombre que Morales Moreno (La modernización, cit., i 8) utiliza para designar lo que describe como "la corriente renovadora del derecho de las obligaciones", corriente en la que se sitúan "los cambios que se han producido en el modo de entender la vinculación contractual, el incumplimiento y sus consecuencias", y que, como explica el autor, no sólo tienen lugar en el derecho español, sino que "se han producido y se están produciendo en un ámbito superior: el del derecho uniforme, el comunitario de la Unión Europea, y en general en el derecho comparado".

22 Por todos, Morales Moreno, La modernización, cit., 30-3 I.

23 La siguiente muestra, de tres autores, basta para ilustrar lo dicho en el cuerpo del texto:

a) Para Carrasco Perera, los remedios frente al incumplimiento son siete: "(i) acción de cumplimiento en forma específica; (ii) cumplimiento por equivalente a costa del deudor; (iii) indemnización de daños; (iv) suspensión del propio cumplimiento; (v) rebaja del precio; (vi) resolución del contrato; (vii) restitución del enriquecimiento obtenido por el deudor con la infracción obligacional", y todo ello sin perjuicio de anunciar la existencia de otros remedios "idiosincráticos para contratos específicos" (Carrasco Perera, Derecho de contratos, cit., io47).

b) Gómez Pomar, por su parte, entiende que los remedios son cuatro: "el cumplimiento en forma específica o cumplimiento forzoso; la indemnización de daños y perjuicios; pena convencional; y resolución” (Gómez Pomar, F., "El incumplimiento contractual en el Derecho español”, en Indret 3/2007, I3). Pero, el mismo autor admite, por un lado, que pueden mencionarse otros remedios (con lo cual llega a enumerar siete, aunque sin coincidir exactamente con los siete que enumera CARrasco): “[e]s cierto que podrían mencionarse otros, señaladamente: la reparación o sustitución de la prestación no conforme con el contrato [...]; la reducción del precio [...]; la exceptio non adimpleti contractus (implícita en los arts. I466 y I 502 c.c.)” (ibíd., I3). Para luego 
[9] Ahora bien, centrando la atención en el remedio del cumplimiento específico, y miradas las cosas desde la perspectiva moderna, quisiera destacar tres ideas.

- En primer lugar, que la pretensión de cumplimiento, en cuanto remedio frente al incumplimiento contractual, hoy "ensancha" su contenido, dando cabida también a la reparación y a la sustitución de la prestación no conforme con el contrato, al menos en ciertos casos; y ello, pese a que tales conductas (reparar y sustituir) no fueran inicialmente asumidas por el deudor como parte de la obligación ${ }^{24}$.

puntualizar que "desde el punto de vista conceptual algunos de ellos no son en realidad sino variantes de tres grandes tipos de remedios en el plano teórico: remedios de conducta forzada del contratante incumplidor [...]; remedios monetarios [...]; remedios de ineficacia" (ibíd., p. I3; las cursivas son entrecomillado en el original). Así -sigue el autor- "la reparación y sustitución (por el contratante incumplidor) son en verdad cumplimiento en forma específica, la reducción del precio es un remedio en dinero analíticamente englobable en la indemnización de daños, y la exceptio non adimpleti contractus es una suspensión de la eficacia contractual, no alejada conceptualmente - aunque sea temporal- de la resolución" (ibíd., I3).

c) Morales Moreno (La modernización, cit., 3o) enuncia cinco remedios: "la pretensión de cumplimiento, la suspensión del cumplimiento de la propia obligación [...], la resolución, la reducción del precio, la indemnización de daños". Reitera esta enumeración en un trabajo más reciente: "[los remedios] [s]on, en concreto: la pretensión de cumplimiento y la indemnizatoria (remedios aplicables a todos los contratos); la suspensión del cumplimiento de la propia obligación, por parte del acreedor; la resolución del contrato; la reducción del precio (en los contratos bilaterales, con obligaciones recíprocas)" ("Claves de la modernización del Derecho de Contratos", en Consejo General del Notariado, Autonomía de la voluntad en el Derecho privado. Estudios en conmemoración del I 5 o aniversario de la Ley del Notariado, t. III-I, Wolters Kluwer, 20I 2, 397).

24 "En el nuevo modelo del Derecho de la contratación se produce un cambio: se ensancha el contenido de la pretensión de cumplimiento, más allá del contenido primario de la prestación. La actuación correctora del deudor (en nuestro caso el vendedor), orientada a subsanar el incumplimiento (mejor, el cumplimiento defectuoso), puede ir más allá del contenido inicial de su deber de prestación; siempre, claro está, dentro de los límites del interés del acreedor garantizado por el contrato [...] Hoy puede afirmarse que la pretensión de cumplimiento tiene por función procurar al acreedor in natura, por medio de la actuación del deudor (y no de la de un tercero), la satisfacción del interés que, conforme al contrato, garantiza el deudor. Va más allá de poder exigir al deudor el dar, hacer o no hacer en que consiste la prestación": Morales Moreno, 2OI 2, 402). En este mismo sentido, también Morales Moreno, La modernización, cit., 82; Gómez Pomar (2007) I3, y Esteban de la Rosa y Gómez Valenzuela, 2013, i6o3. Conviene recordar que el derecho del acreedor a la reparación y a la sustitución es un derecho que está reconocido en la Directiva 1999/44/CE. En el derecho español, ese derecho preferente a la reparación y sustitución, que establece la Directiva 1999/44/CE, se encuentra recogido en los arts. I I 8 a I 20 del Texto Refundido de la Ley General para la Defensa de los Consumidores y Usuarios (en adelante, TRLGDCU), como un derecho del comprador-consumidor. En todo caso, conviene destacar que el derecho a la reparación o sustitución lo es a la reparación o sustitución del producto, y conforme al art. 6 TRLGDCU, producto es "todo bien mueble"; de modo que no es un derecho que resulte aplicable a la prestación defectuosa de servicios (sin perjuicio de la aplicación de este régimen a los contratos de fabricación de bienes de consumo, contratos que, en todo caso, se consideran compraventa). El derecho a la reparación y a la sustitución también está reconocido, como parte integrante de la pretensión de cumplimiento, en otros textos que sirven como modelos de modernización del derecho contractual, como son los Principios Unidroit, los PECL Y el DCFR. 
- En segundo lugar, que la idea de que el acreedor tiene un derecho al cumplimiento especifico es una idea que boy puede ponerse en tela de juicio, en la medida que se plantea la razonabilidad de admitir o incorporar otros límites al cumplimiento, distintos de los de la imposibilidad ${ }^{25}$ y la buena fe, como son, por ejemplo, el hecho de que el cumplimiento sea excesivamente gravoso para el deudor, o el hecho de que el acreedor pueda realizar una operación de reemplazo ${ }^{26}$.

25 Conviene apuntar aquí que, desde la perspectiva moderna, la imposibilidad ya no se mira como una causa de extinción de la obligación, sino que se le considera una causa que excluye la pretensión de cumplimiento, pero no los demás remedios. En este sentido, "[1]a imposibilidad sobrevenida de la prestación es una causa que impide el ejercicio de la acción de cumplimiento y que, por consiguiente, genera una situación de liberación del deudor respecto de tal acción" (L. DítzPicazo, Fundamentos II, 69 I; cursivas añadidas). Desde esta perspectiva, el que la imposibilidad sea un límite de la pretensión de cumplimiento no se justifica en una razón jurídica, sino que es un límite que viene impuesto por la naturaleza de las cosas (cfr. Morales Moreno, La modernización, cit., 67).

26 En este sentido, Morales Moreno (La modernización, cit., 68) explica: “[e]l nuevo derecho de la contratación, aunque reconozca al acreedor la pretensión de cumplimiento, que le permite satisfacer in natura su derecho, establece en ocasiones límites a su ejercicio, no fundados en la imposibilidad, sino en otras causas, en las que sin duda están presentes los criterios económicos: la ponderación del coste que la ejecución supone para el deudor con el beneficio que puede obtener el acreedor, la mejora del funcionamiento del mercado, etc.”. El propio Morales Moreno ofrece dos ejemplos en los que los tribunales españoles han reconocido la indemnización de daños como vía alternativa al cumplimiento in natura, fundado en que, en el caso, el cumplimiento resultaba excesivamente costoso y desproporcionado. El primero de esos casos es una sTc, que Morales Moreno identifica por su fecha y publicación: "stc de I 7 de noviembre de i99 I (воE I 5-I I-I99I)" -se refiere a la stc (Sala i. ${ }^{a}$ ) de i 7 de octubre de i99i (i94/I99i), Ponente: Magistrado D. F. García-Mon y González-Regueral (вое n. ${ }^{\circ} 74$ de I 5 de noviembre de г99і)-. En este primer caso, A interpuso una acción reivindicatoria de un terreno en contra de B. B es condenado a restituir la propiedad, libre de escombros y materiales. En la ejecución (en primera y en segunda instancia) se consideró que no era posible cumplir la sentencia en sus propios términos, porque el costo de limpieza del terreno era cincuenta millones de pesetas, mientras que el valor del terreno apenas sobrepasaba las cien mil pesetas. A recurrió de amparo ante el Tribunal Constitucional, que lo rechazó, confirmando el criterio de solución utilizado por los tribunales de instancia. El segundo de los casos citados por Morales Moreno es una sts que el autor identifica sólo por su fecha (O2-07-I998). En este segundo caso, el Tribunal Supremo, fundándose en la citada sTc, expone: "en el presente caso, es innegable que la ejecución pretendida por la parte recurrente, aunque exactamente no sea técnicamente imposible de llevar a cabo, sí, su cumplimiento supondría una realización de obras cuyo costo es absolutamente desproporcionado" y que "el presente recurso es de los típicos casos, en que una ejecución extremadamente audaz y laboriosa de cumplir, aparte de costosa, debe ser sustituida o atemperada por una justa y equitativa indemnización pecuniaria o de contenido similar" -STs (Sala I. ${ }^{a}$ ) de 2 de julio de 1998 (Roj 4434/I998), Ponente: Excmo. Sr. D. I. Sierra Gil de la Cuesta (FD r. ${ }^{\circ}$ )-. Como se puede apreciar, en esas sentencias citadas no se discute si puede o no condenarse al deudor al cumplimiento específico; en ellas el problema se plantea en fase de ejecución de la sentencia. Así, el límite al cumplimiento específico basado en criterios económicos no aparece (no al menos en estos fallos citados) como un límite de naturaleza sustantiva (es decir, que impida obtener una condena al cumplimiento específico), sino que aparece como un límite de naturaleza procesal (el coste de ejecución incide en la ejecución in natura de la sentencia condenatoria). Conviene apuntar que esos "nuevos" límites de la pretensión de cumplimiento, a los que se refiere Morales Moreno, están presentes tanto en el derecho comparado como en los textos que sirven de modelo para la modernización del derecho contractual. 
- $Y$, en tercer lugar, que parece posible afirmar que ba perdido fuerza la idea de que el remedio del cumplimiento específico sea el remedio preferente, frente a la satisfacción por vía sustitutiva.

Ello, por las siguientes razones:

i. Por un lado, porque en la doctrina se ha propuesto que, aun cuando la prestación sea todavía posible, el acreedor puede optar por la indemnización de daños, si ha perdido el interés en la prestación ${ }^{2}$. Y además, porque se abre la puerta a la posibilidad de que el acreedor pueda realizar una operación de reemplazo, y que pueda luego repercutir la diferencia (el mayor coste o el menor precio obtenido; lo que hace a través del remedio indemnizatorio), lo cual es un claro ejemplo de que la pretensión de cumplimiento pierde ese supuesto lugar central entre los remedios ${ }^{28}$.

ii. Por otro lado, porque, como se sabe, el acreedor puede, en caso de un incumplimiento de cierta entidad, optar entre el cumplimiento y la resolución del contrato (art. I I 24.II c.c.) ${ }^{29}$. Y hoy -entiende la doctrina- se abre paso la idea de

27 Pantaleón Prieto explica: "el acreedor que tenga a su disposición la pretensión de cumplimiento, en el caso de que concurra también el supuesto de hecho de la responsabilidad contractual, no podrá optar exclusivamente por esta, liquidando como daño el valor del objeto de la obligación originaria, cuyo cumplimiento es aún posible, salvo que haya decaído su interés en la prestación" (I99I, I049-I050; cursivas añadidas). Y con mucha más claridad, en otro lugar, el mismo autor se muestra favorable a otorgar al acreedor la posibilidad de optar entre el cumplimiento in natura y el valor de la prestación, lo que plantea como propuesta de lege ferenda (Pantaleón Prieto, F., "Las nuevas bases de la responsabilidad contractual", en adc, n. ${ }^{\circ}$ 46, I993, I 73 I).

28 En este sentido, Morales Moreno: “[e]l moderno Derecho de contratos está procediendo a redefinir el papel de la pretensión de cumplimiento y el de la indemnizatoria en el sistema de remedios del incumplimiento [...] [E]n el nuevo modelo de contrato está tomando carta de naturaleza la operación de reemplazo, como medio para satisfacer, in natura, el interés del acreedor, por un tercero, a costa del deudor. Porque la satisfacción del interés del acreedor puede conseguirse sin que, necesariamente, tenga el deudor que ejecutar su prestación. Puede conseguirse a través de una operación de reemplazo, en la que es un tercero el que satisface al acreedor, con cargo al deudor. Tal operación la sufraga el deudor, por la vía de la pretensión indemnizatoria" (Claves de la modernización del Derecho de Contratos, cit., 400).

29 Del hecho de que el acreedor tenga una opción entre el cumplimiento y la resolución deriva el que no sea posible proponer que la pretensión de cumplimiento sea un remedio preferente frente a la resolución del contrato. En este sentido, Fenoy Picón expresa: “en el sistema general de los remedios del incumplimiento del Código Civil, la pretensión de cumplimiento (reparación, sustitución) y la resolución operan en plano de igualdad (art. I I 24.I c.c.; siendo el incumplimiento grave)" (Fenoy Picón, N., El sistema de protección del comprador, Madrid, Cuadernos de Derecho Registral, 2006, I 7 I). Sin embargo, que se pueda o no predicar una preferencia del cumplimiento sobre la resolución es, básicamente, una cuestión de perspectiva: si se parte de la base de que cualquier falta de cumplimiento de la obligación, por más mínima que sea, permite exigir el cumplimiento íntegro y en los términos pactados (incluyendo dentro del remedio de cumplimiento la subsanación de la prestación defectuosa), y se considera que, en cambio, no cualquier incumplimiento permite al acreedor instar la resolución (la resolución requiere que el incumplimiento sea de cierta entidad), entonces sí que puede admitirse la conclusión contraria: que para el ordenamiento jurídico, el cumplimiento es un remedio preferente respecto de la resolución (en este sentido, véase PINтo Ruiz, J., "Estudio sobre el artículo I I 24 del Código Civil”, en ARAJL, 20 I I, especialmente 259-562). 
que la indemnización de perjuicios que puede acompañar a esa resolución no se limita al interés negativo, sino que puede considerar el interés positivo ${ }^{\circ}$.

iii. Y, en definitiva, porque hoy parece rechazarse la idea de que, en el régimen general del Código Civil, los remedios frente al incumplimiento estén organizados de forma jerárquica ${ }^{3}$.

Como corolario de todo lo que se ha dicho, creo oportuno reproducir, por su contundencia, las palabras de Gómez Pomar:

Dígase lo que se diga, y pese a algunas manifestaciones retóricas del Tribunal Supremo a estos efectos, la verdad es que el cumplimiento forzoso no aparece con claridad en el Derecho español del contrato como el remedio general y preferente frente al incumplimiento contractual. Es general, sí, pero no necesariamente preferente

30 En este sentido, explica Morales Moreno que "[e]l cambio que se ha producido en el tratamiento de la resolución dentro del ordenamiento español, tiene también consecuencias sobre el interés indemnizable, en la indemnización que acompañe a la resolución. Éste es un extremo que fue discutido en nuestra doctrina. Algunos autores (Delgado Echeverría, Jordano Fraga) consideraron que lo oportuno es indemnizar el interés negativo. Lo cual podría explicarse por la aplicación del régimen de la condición resolutoria: el carácter retroactivo del efecto resolutorio coloca la situación en el momento de la celebración del contrato. Pero las críticas que ha merecido la generalización de la doctrina de la retroacción de los efectos de la condición resolutoria cumplida y el hecho de que la resolución se considere un remedio frente al incumplimiento del contrato, explica que se vaya abriendo paso la doctrina favorable al interés positivo" (La modernización, cit., 43-44; cursivas añadidas). En un sentido parecido, Gómez Calle: "[s]i se parte de que la resolución no extingue retroactivamente el contrato [...] lo coherente con ello es sostener que la medida de la indemnización debe venir dada por el interés contractual positivo. No se trata de colocar a quien resuelve en la posición patrimonial en que se hallaría de no haber contratado (interés negativo), pues lo cierto es que ha celebrado un contrato perfectamente válido, y que el mismo ha sido incumplido por la contraparte. No bay razón, por tanto, para privarle de las ventajas que ese contrato le habría reportado de haber sido debidamente cumplido; de ahí que la indemnización deba extenderse al interés positivo" (Gómez Calle, E., "Los remedios ante el incumplimiento del contrato: Análisis de la Propuesta de Modernización del Código Civil en materia de obligaciones y contratos y comparación con el Borrador del Marco común de referencia”, en $A D C, \mathrm{n}^{\circ}{ }^{6} 6$, 20 I 2 (I) 96; cursivas añadidas).

3 I En contra de una jerarquía de los remedios en el sistema del Código Civil, por ejemplo, Fenoy Picón, quien agrega, a lo ya indicado en relación con la resolución (supra nota 29), que "[1]a posibilidad de la reducción del precio puede construirse, aunque no sea lo correcto, a través de la indemnizatoria y operando con carácter alternativo a los anteriores. Dicho de otra forma, en el régimen general del incumplimiento del Código Civil no hay jerarquía de remedios, si bien no bemos de olvidar que cada uno de éstos tiene sus límites (al menos, el fáctico de la imposibilidad, y el que la buena fe establezca en la determinación del grado a partir del cual un remedio ha de calificarse de desproporcionado)" (El sistema de protección, cit., I 7 I ; cursivas del original). Conviene recordar que el TRLGDCU, en cambio, ordena los remedios del comprador-consumidor de manera jerárquica: así, el art. i 8 establece que "el consumidor y usuario tiene derecho a la reparación del producto, a su sustitución, a la rebaja del precio o a la resolución del contrato, de acuerdo con lo previsto en este título"; y el art. I 20, por su parte, señala que "[l]a rebaja del precio y la resolución procederán, a elección del consumidor y usuario, cuando éste no pudiera exigir la reparación o la sustitución...”. Sobre ello véase, por ejemplo, BeCH SERRAT, quien además discute la conveniencia de conservar tal jerarquía (Bech Serrat, J. M., "Reparar y sustituir cosas en la compraventa: evolución y últimas tendencias", en Indret I/2010, especialmente 38-4I). 
frente a, pongamos, la indemnización de daños y perjuicios en todas las manifestaciones y modalidades del incumplimiento contractual ${ }^{32}$.

\section{B. El cumplimiento específico en las obligaciones de hacer: el artículo ro98 c.c.}

[ı。 Lo hasta ahora dicho se refiere al cumplimiento específico en general. La pregunta que surge es si existe alguna particularidad, cuando se examina la cuestión desde la perspectiva de las obligaciones de hacer. Y para ello es necesario considerar lo que el art. Io98 c.c. dispone: "Si el obligado a hacer alguna cosa no la hiciere, se mandará ejecutar a su costa. / Esto mismo se observará si la hiciere contraviniendo el tenor de la obligación. Además, podrá decretarse que se deshaga lo mal hecho".

De su sola lectura resulta claro que el art. Iog 8 c.c. no consagra expresamente un derecho del acreedor a que se condene al deudor al cumplimiento específico de la obligación de hacer, ni impone al acreedor un deber de solicitar tal condena. Las consecuencias establecidas en este artículo, para el caso de incumplimiento de la obligación de hacer, son otras (mandar ejecutar la prestación a costa del deudor; decretar que se deshaga lo mal hecho). Pese a ello, parece posible afirmar que la idea tradicional de que existe un derecho al cumplimiento específico, y que este es la vía preferente de satisfacción, alcanza también a las obligaciones de hacer ${ }^{33}$. La lectura que se hace de este art. Io9 8 c.c., tanto por parte de la doctrina como por parte de jurisprudencia, avala dicha conclusión.

Gómez Pomar, 2007, i6; cursivas añadidas.

33 En este sentido, Moreno Quesada explica que, cuando ha habido incumplimiento, "la Ley pretende que [el] patrimonio [del acreedor] quede finalmente como si hubiese habido un cumplimiento: y para ello, sin duda, el mejor procedimiento es facilitarle el comportamiento omitido, procurárselo de la misma forma en que debió ser y no fue realizado por el deudor; lo que se denomina cumplimiento específico que, por la forma en que va a darse, hay que calificar como forzoso. ¿Y cuál es la forma de actuarlo? En principio [...] mediante la 'acción de cumplimiento' [esta solución se justifica porque] es la más justa y acorde con el concepto de obligación, ya que con la misma se persigue obtener la prestación, y no una indemnización, quedando ésta sólo como último recurso para cuando aquélla no pueda obtenerse, o en tanto en cuanto no pueda serlo exactamente" ("Problemática de las obligaciones de hacer", en RDP, n. 60, I976, 494). Desde luego, es posible plantear que el art. I I 24. .I c.c. provee una base normativa al remedio del cumplimiento específico de las obligaciones de hacer. Esto, por cuanto señala que "[e]l perjudicado podrá escoger entre exigir el cumplimiento o la resolución de la obligación, con el resarcimiento de daños y abono de intereses en ambos casos..."; reconociendo, como se ve, el derecho de la parte cumplidora a exigir el cumplimiento, sin distinguir si se trata de una obligación de dar, de hacer o de no hacer. Pero, lógicamente, el fundar el derecho del acreedor al cumplimiento específico de la obligación de hacer en el art. I I24.II c.c. sólo es admisible respecto de contratos sinalagmáticos. 


\section{La doctrina}

[i I] De la lectura que del artículo io9 8 c.c. hace la doctrina española me interesa destacar los siguientes cuatro aspectos:

- Primero. Como se ha dicho, el art. ro98 c.c. contempla dos consecuencias para el caso del incumplimiento de la obligación de hacer. Pues bien, se entiende que la consecuencia establecida en el art. iog8.i c.c. ("se mandará ejecutar a su costa") es una forma de ejecución forzosa, si bien se advierte que no se trata de una vía que opere directamente contra el deudor, sino que opera contra su patrimonio. O sea que se trata de una forma de cumplimiento, pero "indirecta" 34 . En cambio, se entiende que la consecuencia establecida en el art. Io98.in c.c. ("podrá decretarse que se deshaga lo malhecho") no es una forma de cumplimiento, sino una forma de reparación (es reparación en especie) ${ }^{35}$.

- Segundo. Se entiende que la consecuencia establecida en el art. Io98.I c.c. (“se mandará ejecutar a su costa") es una consecuencia que resulta aplicable únicamente a las obligaciones de hacer no personalísimas o fungibles ${ }^{6}$. La razón es que

34 En este sentido, explica DE Diego que "[h]ay obligaciones de hacer y de no hacer en que es posible el cumplimiento específico, a pesar de la resistencia del deudor, e independientemente de su concurso. En esos casos no se va por el pronto exclusivamente a la indemnización de daños, sino al medio supletorio de poder obtener el cumplimiento de la obligación. Me prometisteis construir un edificio que no me lo construís en absoluto, pues es cierto que nemo precise ad factum cogi potest, pero puedo pedir autorización al juez para que yo le construya a tus expensas. No es transformación de la obligación primitiva en una nueva (novación) teniendo por objeto una nueva pecuniaria por la indemnización en lugar del objeto propio de la obligación, sino forma indirecta y única posible de su cumplimiento" (Instituciones, t. 2, 68; cursivas añadidas). Por esta razón-explica el mismo autor- no es cierto lo que establece el art. I I 42 Code civil, siendo justificado, en su opinión, que el Código Civil español no lo haya recogido (cfr. ibíd., 69). En este mismo sentido se ha dicho que "[e]l art. Io98 al admitir la ejecución forzosa en las obligaciones de hacer, zanja una vieja discusión en la que había predominado la opinión contraria, por considerar que implicaba una violencia sobre la persona del deudor. Precisamente esta objeción ha sido tenida en cuenta como lo demuestra que la ejecución se haga al margen de la persona del deudor, ya que el art. Io98.i no dice que la ejecutará el deudor, sino que se 'mandará ejecutar' actuando solamente sobre su patrimonio ('a su costa')": Badosa Coll, F., “Comentario del art. io98”, en Paz-Ares et al. (dirs.), Comentario del Código Civil, Madrid, Ministerio de Justicia, ı993, t. 2, 30; cursivas añadidas.

35 "Para el art. Io98.II se trata de una medida integrante de la ejecución forzosa, de la que sería un reforzamiento; sin embargo no es así. El 'deshacer' lo mal hecho no pertenece a la ejecución forzosa sino a la indemnización de daños y, en concreto, a su reparación in specie. En efecto la petición del acreedor de 'deshacer' lo mal hecho solo es concebible cuando lo contempla como un perjuicio incompatible con el cumplimiento; su destrucción debe, pues, someterse al régimen de aquél, no al de éste. Su no consideración como indemnización y sí como ejecución forzosa se debe a que el art. i io r se limita a la indemnización como obligación accesoria, y por tanto, dineraria, mientras que el art. rog 8 trata de 'medidas' judiciales entre las cuales se halla claramente la 'destrucción”": Badosa Coll, i993, 30.

36 En este sentido, por ejemplo, ya Scaevola: "[el] art. Io98 se refiere solo a los hechos que pueden ejecutarse indistintamente por el deudor o por tercera persona" (Comentarios al Código Civil, t. i9, 430: comentario del art. io98; cursivas añadidas]; y Manresa y Navarro: "entiéndase que la procedencia y eficacia de tal medio [se refiere a la ejecución por otro y a costa del deudor] no tendrán lugar cuando la prestación consista en actos personalísimos del deudor, o en las cualidades especiales que en él concurran, v. gr. las dotes de un artista, sean motivo determinante de la obligación 
las obligaciones de hacer personalísimas o no fungibles no admiten, por su propia naturaleza, la posibilidad de que otra persona, distinta del deudor, sea quien realice la prestación ${ }^{37}$. En consecuencia, nada puede desprenderse del art. Iog 8 c.c. en relación con el derecho al cumplimiento especifico, si la obligación es personalísima.

- Tercero. Esa medida de "cumplimiento" ("se mandará ejecutar a su costa") parece suponer la actuación del juez y, por tanto, supone también el ejercicio previo de la acción de cumplimiento (ello deriva del empleo de la expresión "se mandará"). Esto quiere decir que se excluye la posibilidad de que el acreedor pueda contratar directamente a un tercero para que este sea quien realice la prestación debida (y reclamar posteriormente el costo de ello al deudor) $3^{3}$.

contraída; en tales casos la ejecución del acto por otro, o no tendría utilidad ninguna, y aun a veces sería imposible, o resultaría tan distinta que no pudiera considerarse satisfecha la facultad del acreedor. Que así debe entenderse es en el orden lógico evidente, y que así como no podía menos de suceder lo entiende el legislador, lo prueba el art. i i6 I [...] [P] ara tales casos no queda, por consiguiente, más que un medio de reparación, ya no de cumplimiento: la indemnización de daños y perjuicios" (Manresa y Navarro, J. M., Comentarios al Código Civil, t. 8, 2. ed., i 907, 52: comentario del art. I908; cursivas añadidas, ortografía modernizada). Y en el mismo sentido, por ejemplo, Badosa Coll: "de ahí que la ejecución forzosa [del art. Io98] no quepa cuando la prestación es 'personalísima', caso en que sólo cabrá la obligación de indemnizar” (I993, 30). Todos los anteriores autores escriben en vigencia de la LEC de I88I.

Más recientemente, en este mismo sentido, Verdera Server: "[1]a solución del artículo iog8.I no admite ser trasladada al caso de la ejecución forzosa de obligaciones de hacer personalísimas, en las que, por definición, el deudor no puede ser sustituido por nadie en el cumplimiento de su obligación ('rectius' su hipotética sustitución no satisfaría el interés del acreedor [...]) de modo que el mecanismo del mandato de ejecución a su costa no resulta operativo" ("Comentario del artículo io98”, en Cañizares, A.; De Pablo, P.; Orduña, J. y Valpuesta, R. (dirs.), Código Civil comentado, Navarra, Thomson-Civitas y Aranzadi, 20 I I, v. 3, I 290).

37 Conviene recordar que, para la doctrina civil, la prestación de hacer es fungible "cuando el acreedor queda satisfecho con una pura actividad, cualquiera que sea quien la realice"; en cambio, es infungible "cuando la persona que ha de prestar su actividad constituye un elemento esencial del programa de prestación y no puede ser sustituida por otra. El comportamiento debido se llama en estos casos personal o "personalísimo"': L. Díez-Picazo, Fundamentos II, cit., 279. Para determinar si en un caso la obligación es fungible o no hay que considerar varios factores, entre ellos: la declaración de las partes, las circunstancias en que se ha celebrado el negocio, la naturaleza del negocio, etc. (ibíd., 279). Para un análisis en profundidad de esos factores véase, por ejemplo, Moreno Quesada, "Problemática de las obligaciones de hacer", en $R D P, \mathrm{n}^{\circ}$ 6o, i976, 470-474, y Manrique De Lara Morales, "La ejecución forzosa de la obligación de hacer infungible”, en $A D C$, n. $^{\circ} 54,200$ I (3), I I69-I I 80. En este sentido, el que la consecuencia del art. ıo98.i c.c. ("se mandará ejecutar a su costa”) no sea aplicable a las obligaciones de hacer personalísimas es una idea que suele afirmarse en conexión con lo dispuesto en el art. I I6 I c.c. ("En las obligaciones de hacer el acreedor no podrá ser compelido a recibir la prestación o el servicio de un tercero, cuando la calidad y circunstancias de la persona del deudor se hubiesen tenido en cuenta al establecer la obligación”); así, por ejemplo, Martín Pérez, "Comentario del artículo rog8”, en Albadalejo, M. (dir.), Comentarios al Código Civil y compilaciones forales, Madrid, Edersa, I978, t. I 5, v. I, 330.

38 Moreno Quesada, tras analizar la cuestión, concluye que "quizás pudiera defenderse la posibilidad de una ejecución directa por el acreedor, a expensas del deudor, siempre que: I. ${ }^{\circ}$ Le dirija una previa intimación, comunicándole las circunstancias en que piensa hacerla. $2^{\circ}[\ldots]$ [P]ueda llevarla a cabo en su propia esfera de actuación, invadir el ámbito posesorio del deudor [sic; seguramente deba leerse 'sin invadir']; y $3 .{ }^{\circ}[\ldots]$ [E]xista necesidad de actuar así, lo que hay que entender en el sentido de que estando la obligación cumplida, el retraso vaya a producir la 
- Y cuarto. Se entiende que el art. Io98 c.c. es una norma de naturaleza procesal39; y de ahí su vinculación con las reglas de ejecución que contempla la LEC $^{40}$. En este sentido, se entiende que la consecuencia establecida en el art. Io98.I c.c. ("se mandará ejecutar a su costa") es una consecuencia que opera en fase ejecutiva, o sea, en el caso en el que el deudor no cumpla con la sentencia que lo condena a realizar la prestación ${ }^{4}$. $Y$ ello supone, por tanto, que una sentencia, que condene al propio deudor al cumplimiento específico, si es posible ${ }^{42}$. Sentencia que es posible, pero no necesaria, pues se entiende que el art. ro98 c.c. "no impone una jerarquía u orden de remedios de Derecho material" 43 .

\section{La jurisprudencia}

[i 2] En la jurisprudencia del Tribunal Supremo, el art. Io98 c.c. es citado casi exclusivamente en relación con el supuesto del art. I 59 I.I c.c.; esto es, en rela-

imposibilidad de un cumplimiento posterior, o mejor, de la satisfacción in natura del interés del acreedor, lo que viene a significar tanto como urgencia" (Moreno Quesada, ob. cit., 494-496; la cita textual en p. 496). Sobre el punto, también Martín Pérez, ob. cit., 336-337.

39 Como señala Carrasco Perera, "[b]asta detenerse en la lectura desapasionada del precepto para comprender que en él se contiene una norma de naturaleza procesal cuyo destinatario es el juez" (Carrasco Perera, Á., "Reparación en forma específica y reparación a costa del deudor en la responsabilidad por ruina", en Indret, I/2006, , o; cursivas del original).

40 Sobre la estrecha vinculación del art. Io98 c.c. con las reglas procesales de ejecución, valga lo dicho supra notas 2, 3 y 4 . En este sentido, resulta interesante apuntar que ScaEvola refiere, como antecedentes del art. Io98 c.c., ciertas leyes de las Partidas, que son, en realidad, reglas sobre ejecución (de naturaleza procesal) [cfr. Scaevola, 424-425]. Sobre esas leyes de las Partidas, referidas al derecho del acreedor al cumplimiento específico, y en general, sobre el derecho al cumplimiento específico en el Derecho español antes de la entrada en vigor del Código Civil, véase: Severin Fuster, G., "El derecho al cumplimiento específico de la obligación de hacer en la doctrina española del siglo xIx anterior a la codificación civil", Revista de Estudios Históricofurídicos, n. $^{\circ} 37,2015,377-397$.

4I Como explica Carrasco Perera: "[s]i es el juez el que 'manda ejecutar' el incumplimiento de la obligación de hacer tiene que haberse producido dentro del proceso de ejecución. Es decir, el juez manda ejecutar a su costa en un determinado momento o incidente del proceso de ejecución. ¿Mas cuál es el título ejecutivo que se actúa en este proceso? Sin duda que no puede serlo una sentencia que condene (o permita) a que se cumpla a costa del deudor o que condene al deudor a pagar un dinero en concepto de satisfacción equivalente. La sentencia que se ejecuta es la que impone específicamente al deudor la condena de hacer. En consecuencia, el "incumplimiento" ante cuya producción se actúa la ejecución sustitutoria es el incumplimiento de la sentencia de condena de hacer, no el incumplimiento bistórico de la obligación civil de hacer, que condujo a la demanda y al proceso" (Carrasco, 2006, Io; cursivas del original).

42 En este sentido, Morales Moreno explica: "[sin perjuicio de que] los artículos rog6, Io97 y ro98 contemplan medidas de ejecución que, fundamentalmente, cobran sentido dentro del proceso de ejecución [...] su enunciación en el Código Civil implica, de algún modo, el reconocimiento del derecho del acreedor a exigir judicialmente, si fuere necesario, el cumplimiento de la obligación. $\mathrm{O}$, dicho de otro modo, el derecho a postular al juez que dicte una sentencia de condena al cumplimiento de la obligación, ejecutable, en principio, en sus propios términos" (La modernización, cit., 78 ; cursivas añadidas). 
ción con la responsabilidad del contratista por los vicios ruinógneos del edificio44.

Conviene advertir que esa vinculación que hace el Tribunal Supremo entre los artículos I098 y I 59 I c.c. supone confundir dos cosas distintas: la pretensión de cumplimiento "específico" (o "in natura”) y la acción de reparación, que puede ser in natura 45 . El art. I 59 I c.c. se refiere claramente a la acción de reparación, no a la de cumplimiento (los términos empleados en este artículo son claros: se dice que el contratista "responde de los daños y perjuicios"; y se habla de "la acción de indemnización”).

Dicho esto, y aun cuando, en puridad, esas sentencias del Tribunal Supremo no se refieren al remedio del cumplimiento específico, el hecho de que se utilicen indistintamente los términos "reparación en forma específica" y "cumplimiento en forma específica" 46 justifica referirse a dichas sentencias.

[13] Como principio, el Tribunal Supremo viene sosteniendo que la forma de exigir la responsabilidad por vicios ruinógenos es mediante el ejercicio de una "acción de cumplimiento de contrato", por la que se condena a realizar una obligación "de hacer", y que esa obligación de hacer "ha de ser cumplida en forma específica, de acuerdo con el art. Io98 del Código”. Según esta línea jurisprudencial, "el acreedor puede exigir que se realice la prestación en forma específica"; pero ello no se entiende como la concesión al acreedor de una opción entre la reparación in natura y la indemnización en metálico; al contrario, el acreedor

44 Art. I59 I c.c.: "El contratista de un edificio que se arruinase por vicios de la construcción, responde de los daños y perjuicios si la ruina tuviere lugar dentro de diez años, contados desde que concluyó la construcción; igual responsabilidad, y por el mismo tiempo, tendrá el arquitecto que la dirigiere, si se debe la ruina a vicio del suelo o de la dirección...”. Conviene apuntar que, tras la entrada en vigor de la Ley de Ordenación de la Edificación (вое n. ${ }^{\circ} 266$ de о6/г I/I 999; en adelante, LOE), la vigencia del art. I59 I c.c. ha sido puesta en entredicho. El art. I7 LOE regula, en extenso, la responsabilidad civil de los agentes que intervienen en el proceso de la edificación. El art. I 8 LOE, por su parte, establece, como plazo para ejercer las correspondientes acciones, el de dos años, contados desde momentos distintos, según se trate de acciones de responsabilidad o de repetición. Existe, por tanto, cierta superposición entre el contenido de estas normas y el contenido del art. I59 I c.c., siendo posible entender que los arts. I 7 y I 8 LOE derogaron tácitamente el art. I59 i c.c.

45 En este punto conviene precisar que el hecho de que hoy se "ensanche" el contenido del remedio del cumplimiento específico (en cuanto da cabida a la reparación y a la sustitución) no permite confundir el cumplimiento con la reparación in natura. En este sentido, Morales Moreno explica: "la pretensión de cumplimiento asume en estos casos [se refiere a los casos en los que incluye la reparación y sustitución] una función que puede recordarnos a la de la indemnización in natura. Pero existen determinadas diferencias: $\mathrm{x} .{ }^{\mathrm{a}}$ La subsanación del incumplimiento, en principio, le corresponde ejecutarla al deudor. Por eso se enmarca en el ámbito de la pretensión de cumplimiento. $2 .^{\text {a }}$ Los requisitos para que el acreedor tenga derecho a la subsanación del incumplimiento (reparación o sustitución) no son los propios de la pretensión indemnizatoria, sino los de la pretensión de cumplimiento. A los que se añaden las particularidades que puedan establecerse para el ejercicio de estos derechos" (2OI2, p. 402; cursivas añadidas). También resalta las diferencias que existen entre la acción de cumplimiento específico y la de reparación in natura, Carrasco Perera, 2006, I3.

46 Acusa también esta confusión, por parte de los tribunales, Carrasco Perera, 2006, 5 y I 3. 
debe demandar el cumplimiento específico, y sólo si este no es posible, se puede condenar al deudor a la indemnización en dinero. Es más, si el acreedor sólo demanda la indemnización en dinero, la pretensión de cumplimiento específico debe entenderse incluida en el petitum de la demanda47.

Y, por lo mismo, si el demandante no ha pedido el cumplimiento específico, el tribunal, al condenar al cumplimiento específico, no otorga cosa distinta de lo pedido, ni causa perjuicio la sentencia que condena al demandado a la reparación en forma específica, pues, al hacerlo así, el Tribunal pone en manos del deudor la opción entre la reparación en metálico y la reparación in natura ${ }^{4}$.

Esta interpretación del Tribunal Supremo ha marcado una línea jurisprudencial bastante clara, que en la actualidad es seguida por las audiencias provinciales 49 .

47 Todas las ideas arriba indicadas se encuentran en la sтs (Sala I. ${ }^{a}$ ) de I 2 de diciembre de 1990 , la que, como ella misma expresa, recoge la doctrina asentada por otras de sentencias (la STS I2 de noviembre de I976, la sTs de 3 de julio de 1989 y la sTs 2 I de octubre de I990). Al respecto, se dice: "La obligación de responder de los daños y perjuicios que impone el artículo r.59I del Código Civil [...] es exigible judicialmente a través del ejercicio de una acción de cumplimiento de contrato del artículo I.09 I del citado Código, constituyendo aquélla una obligación de hacer que ha de ser cumplida en forma específica, de acuerdo con el artículo r.o98 del Código, entrando en juego el cumplimiento por equivalencia, de carácter subsidiario, cuando el deudor no realiza la prestación debida o ésta deviene imposible [...] en las obligaciones de hacer, el acreedor puede exigir que esa prestación se realice en forma específica (acción de cumplimiento), siendo esta obligación de cumplir la primera y directa consecuencia del incumplimiento imputable, que en ocasiones puede conseguirse coactivamente aun contra la voluntad del deudor; así el artículo r.098 del Código Civil dispone que 'si el obligado a hacer alguna cosa no la hiciere, se mandará ejecutar a su costa'. Tan sólo en el caso en que no pueda conseguirse el cumplimiento voluntario o forzoso de la obligación entra en juego el principio 'nemo factum cogi potest' y la prestación primitiva se transforma en la de indemnizar. A tenor del suplico de la demanda y los hechos en que la misma se fundamenta es claro que, en el presente caso, se está ejercitando una acción de cumplimiento de contrato instando el cumplimiento forzoso a costa del obligado que sólo puede acordarse de forma sustitutoria y en defecto de la ejecución voluntaria, debiendo entenderse incluida en el 'petitum' de la demanda" -(Roj 9I40/I 990), Ponente: Excmo. Sr. D. P. González Poveda (FD 2...$^{\circ}$-.

48 En este sentido, la sts (Sala I. ${ }^{a}$ ) de 3 de abril de 2000: "La parte recurrente [en el caso, los arquitectos, que fueron demandados a indemnizar pecuniariamente, pero condenados a reparar in natura] tiene razón en cuanto a que en la demanda se pide una condena pecuniaria -prestación de dar-, mientras que en la Sentencia recurrida se condena a los Arquitectos a que realicen las reparaciones de los vicios denunciados - prestación de hacer-. Sin embargo el fallo favorece a los recurrentes porque pueden optar por la sanción específica, o por la sanción genérica de la prestación del 'id quod interest' -cumplimiento por equivalencia” -(Roj 2730/2000), Ponente. Excmo. Sr. J. E Corbal Fernández (FD 2..$\left.^{\circ}\right)$.

49 Por sólo poner algunos ejemplos, acogen esta doctrina y reproducen la explicación, la SAP de Tarragona (Sección I) de I 8 de octubre de 2006 (1493/2006), Ponente: Ilmo. Sr. D. J. L. Portugal Sainz (FD 4 ${ }^{\circ}$ ); la SAP de Salamanca (Sección I) de r 8 de diciembre de 2007 (634/2007), Ponente: Ilmo. Sr. D. I. García del Pozo (FD $3 .^{\circ}$ ); la sap de Pamplona/Iruña (Sección I) de I 7 de febrero de 2008 (517/2008), Ponente: Ilmo. Sr. D. F. Poncela García (FD $\left.3{ }^{\circ}\right)$, y la sap de Madrid (Sección Io) de 18 de noviembre de 2010 (17624/2010), Ponente: Ilmo. Sr. D. Á.V. Illescas Rus (FD 2..$^{\circ}$. 
[I4] No obstante, se observa cierta tendencia a flexibilizar ese principio o regla general. En este sentido, se admite, como una excepción al principio de la preferencia del cumplimiento específico del art. I908 c.c. $5^{\circ}$, que el acreedor puede, bajo ciertas circunstancias, demandar y obtener directamente una condena indemnizatoria. Ello es posible, particularmente:

i. Si el acreedor ba requerido al deudor para que realice las reparaciones, y no ba obtenido respuesta ${ }^{\mathrm{I}}$.

ii. Si el acreedor ba requerido al deudor para que realice las reparaciones, $y$ consta que el deudor se ha negado a ello $5^{2}$.

iii. Si la ejecución de las obras, o su reparación, tienen carácter urgente, con la finalidad de evitar mayores daños 53 .

50 "[E]l derecho a pedir el cumplimiento in natura no excluye la posibilidad de la reclamación directa de la indemnización en su lugar. Pero esta es una excepción a la regla general del artículo Iog 8 c.c. y para ello se requiere: a) que el demandante haya requerido por cualquier medio que debe ser probado la realización de las reparaciones exigidas según el estado de la obra; b) que el demandado haya incumplido la obligación voluntariamente por haber incurrido en dolo o culpa o con contravención del tenor de las obligaciones pactadas [...] y c) que el demandante prefiera la indemnización, dado el constatado incumplimiento del deudor, por depender el cumplimiento de una relación personal que se ha demostrado contraria a las reglas de conducta propias de las relaciones contractuales" -STS (Sala I. ${ }^{\mathrm{a}}$ ) de I3 de julio de 2005 (Roj 4759/2005), Ponente: Excma. Sra. Dña. E. Roca Trías (FD $\left.3 .^{\circ}\right)$ -

5I En este sentido, por ejemplo, la sts (Sala r. ${ }^{a}$ ) de 7 de mayo de 2002: "El hecho de que el actor haya invocado el artículo r59I del Código Civil no puede entenderse que conceda a la recurrente [la empresa contratista, a la que se condenó al pago de una suma de dinero] el privilegio de llevar a cabo por sus propios medios unos importantes trabajos de reparación los cuales aparentemente sobrepasan la mitad del precio de venta de la vivienda dado que dicha entidad se había abstenido de realizarlos eficazmente en los tres años transcurridos hasta la interposición de la demanda pese a los compromisos manifestados" -(Roj 3201/2002), Ponente: Excmo. Sr. D. A. Romero Lorenzo (FD 2..$^{\circ}$ )-. En el mismo sentido, la sTs (Sala I. ${ }^{a}$ ) de 13 de julio de 2005 (Roj 4759/2005), Ponente: Excma. Sra. Dña. E. Roca Trías (FD 3. ${ }^{\circ}$ ).

52 En este sentido, por ejemplo, el ats de 6 de febrero de 200 I (223 I/200I), Ponente: Excmo. Sr. D. J. Almagro Nosete. En esta sentencia, si bien se indica que el derecho que concede el art. I098 c.c. es un derecho "subsidiario" a la petición de que se ordene el cumplimiento en forma específica al propio deudor, se admite que, "constando en autos la negativa de la demandada a realizar las reparaciones requeridas, queda justificada la procedencia de la condena indemnizatoria que, de forma subsidiaria, prevé el precepto citado como infringido" (FD 2. ${ }^{\circ}$ ). Y en el mismo sentido, la ya referida sts (Sala I. ${ }^{2}$ ) de I3 de julio de 2005 (Roj 4759/2005), Ponente: Excma. Sra. Dña. E. Roca Trías (FD $3 .{ }^{\circ}$ ).

53 En este sentido, la sts (Sala I. ${ }^{a}$ ) de 27 de julio de 2007 : "en el presente caso, el dato fundamental a tomar en cuenta a la hora de confirmar la procedencia de la reclamación indemnizatoria formulada, verdadera 'quaestio facti' expresada en la resolución recurrida y que no ha sido desvirtuada en casación, es el carácter de necesidad y urgencia de las obras de reparación acometidas por la actora [...] [La Alcaldía] requirió a la actora para que, en el breve plazo de quince días, acometiese una serie de reparaciones urgentes previa presentación al Ayuntamiento, para su aprobación, de un proyecto redactado por arquitecto superior. Tal urgencia y necesidad estaría en todo caso justificada, vista la entidad de las deficiencias ruinógenas aparecidas, por el hecho de aquejar las mismas a un centro escolar, con consiguiente riesgo para la integridad de los menores que acudían al mismo" -(Roj 7775/2007), Ponente: Excmo. Sr. D. J. Almagro Nosete $\left(\mathrm{FD} 2 .{ }^{\circ}\right)-$. 
Además, en algunas sentencias parece descartarse la idea de que exista una preferencia entre las vías de cumplimiento (reparación), sosteniendo, en cambio, que el art. I 59 I c.c. ofrece al acreedor una alternativa entre tres posibles vías: i) el cumplimiento in natura (esto es, que se condene a los responsables a reparar los vicios); ii) la indemnización de los daños (calculada sobre los costes en los que ya se hubiera incurrido en la reparación), y iii) una indemnización de daños, para que el perjudicado asuma por sí mismo las obras necesarias ${ }^{54}$.

\section{[15] ¿Qué puede concluirse hasta aquí?}

En síntesis, lo siguiente: que, en la medida que "el que se mande a ejecutar por otro" (art. Io98.i c.c.) sea una consecuencia que opera en la fase de ejecución, entonces nada nos dice el art. rog 8 c.c. en relación con la posibilidad de que se condene, o no, al propio deudor a ejecutar la prestación pactada.

En consecuencia, el que sea posible, o no, que se condene al propio deudor a cumplir la obligación de hacer -tanto en las obligaciones fungibles como en las no fungibles- depende de cómo se configure sustantivamente el remedio del cumplimiento especifico, y en particular, de cuáles sean sus límites. Y en este punto, como se ha mostrado, se observa una cierta evolución: la doctrina española moderna tiende a admitir "nuevos" límites al remedio del cumplimiento. A mi juicio, la adopción de esos "nuevos" límites al cumplimiento podría llegar a excluir la posibilidad de que el acreedor pueda obtener una condena al cumplimiento específico de una obligación de hacer. La efectividad de esta última afirmación requiere considerar con mayor detenimiento esos "nuevos" límites al cumplimiento específico, límites que están tomados, en una buena medida, de los modelos de modernización del derecho de contratos (sobre este último punto, sin embargo, no corresponde tratar en este lugar).

54 En este sentido, por ejemplo, la sts (Sala I. ${ }^{a}$ ) de io de marzo de 2004 , la que, rechazando el motivo de casación por infracción del art. I 59 I c.c. (condenado a la indemnización de daños, el recurrente arguye que este artículo no autoriza al demandante a pedir directamente la indemnización de daños), expresa: "el referido artículo I 59I, como actividades reparadoras de los vicios ruinógenos en base a la responsabilidad legal que establece, autoriza las siguientes: a) Obras de subsanación y reparación 'in natura' a cargo del contratista y en su caso del promotor, técnicos y personas que resultasen condenadas, a fin de dejar el edificio en condiciones de seguridad y habitabilidad suficientes [...]; b) Reclamación de reintegro de las cantidades realmente invertidas por la Comunidad de Propietarios en obras restauradoras de los vicios constructivos cuando los gastos correspondientes son exclusivamente de cargo de los que intervinieron en el proceso edificativo y así resulte de sentencia condenatoria, lo que implica que los declarados responsables no los asumieron en su debido tiempo y las reparaciones dinerarias actúan así como las procedentes, pues la ejecución 'in natura' en estos casos daría lugar a dilaciones y conflictos [...]; c) Cuando se plantea demanda, como aquí sucede, para solicitar se fije cantidad determinada para que la Comunidad de Propietarios pueda afrontar por sí misma y atender al costo de los trabajos y actividades necesarias de consolidación, refuerzo y reparaciones en general en las zonas del inmueble afectadas por la situación de ruina que se denuncia, lo que resulta procedente y, en este caso, por el resultado de las pruebas practicadas, la sentencia recurrida fijó el importe en la cantidad de 7.626.695 pesetas..."-(Roj I653/2004), Ponente: Excmo. Sr. D. A. Villagómez Rodil (FD.$\left.^{\circ}{ }^{\circ}\right)$-. 
Paralelamente, la idea de que el acreedor deba intentar primero la satisfacción in natura de su crédito, antes de poder buscar la satisfacción por vías alternativas, es una idea que ha perdido fuerza. Hoy, tanto en la doctrina como en la jurisprudencia, parece abrirse camino la idea de que el acreedor puede buscar la satisfacción de su crédito por la vía que mejor satisfaga su interés.

\section{La perspectiva procesal. El derecho a la ejecución in natura y la idea de que esta es la vía preferente de ejecución}

[i6] Como se ha dicho al comienzo de este trabajo, sólo una vez que el acreedor de la obligación contractual de hacer (el cliente del servicio) ha obtenido a su favor una sentencia en la que se condena al deudor (al prestador del servicio) a realizar la obligación incumplida, es que cabe preguntarse si dicho acreedor tiene derecho al cumplimiento específico (o in natura) de esa condena judicial a realizar la prestación de bacer.

\section{A. El derecho a que la sentencia se ejecute "en sus propios términos". Su reconocimiento y sus límites}

\section{El derecho a la ejecución como manifestación del derecho a la tutela judicial efectiva}

[I 7] El art. 24. I de la Constitución española [en adelante, CE], que se encuentra dentro del Título Primero ("De los derechos y deberes fundamentales"), establece: "Todas las personas tienen derecho a obtener la tutela efectiva de los jueces y tribunales en el ejercicio de sus derechos e intereses legítimos, sin que, en ningún caso, pueda producirse indefensión”.

La garantía constitucional del art. 24. I CE -que la doctrina y la jurisprudencia constitucional denominan sintéticamente como "derecho a una tutela judicial efectiva" 55 - es de contenido complejo, en el sentido de que tiene múltiples manifestaciones, las que se presentan, sobre todo, de cara a la potestad jurisdiccional ${ }^{6}$. Ahora bien, en la medida que la ejecución es parte de la potestad jurisdiccional57,

55 Por todos, Díez-Picazo Giménez, I., “Artículo 24: garantías procesales” en Alzaga Villaamil, O. (dir.) Comentarios a la Constitución Española de 1978, t. 3, Madrid, Edersa, I996, 27.

${ }_{5} 6$ Para una presentación de estas diversas proyecciones (o, si se quiere, para un análisis del contenido de este derecho a la tutela judicial efectiva) véase, por ejemplo, CALAza López, S., "Principales proyecciones del Derecho a la tutela judicial efectiva en la doctrina del Tribunal Constitucional", en RGDP, n. ${ }^{\circ}$ 23, 20 I I, I-35; y también Díez-Picazo Giménez (i996) 3 I ss.

57 En efecto, la doctrina entiende, con base en el art. I I 7.3 CE ("El ejercicio de la potestad jurisdiccional en todo tipo de procesos, juzgando y haciendo ejecutar lo juzgado, corresponde exclusivamente a los Juzgados y Tribunales determinados por las leyes, según las normas de competencia y procedimiento que las mismas establezcan”) que la potestad jurisdiccional no se agota en la mera actividad consistente en la declaración del derecho, sino que la potestad 
el derecho a la tutela judicial efectiva incluye lógicamente un derecho a la ejecución. Tal derecho a la ejecución consiste en el derecho a obtener el cumplimiento efectivo de las sentencias. Así lo entiende la doctrina ${ }^{5}$ y así lo ha dicho claramente el Tribunal Constitucional [en adelante, TC] 59 . Y, como lo ha sostenido el mismo Tribunal, el derecho a la ejecución de las sentencias implica que ellas sean "cumplidas en sus propios términos":

Es doctrina consolidada de este Tribunal que la ejecución de las Sentencias 'en sus propios términos' forma parte del derecho fundamental a la tutela judicial efectiva. Ello significa que ese derecho fundamental lo es al cumplimiento de los mandatos que la Sentencia contiene, a la realización de los derechos reconocidos en la misma, o, de otra forma, a la imposición forzosa a la parte vencida del cumplimiento de las obligaciones a que fue condenada ${ }^{60}$.

jurisdiccional también incluye la ejecución de las sentencias (cfr., p. ej., CaCHÓN Cárdenas, M., Apuntes de ejecución procesal civil, Universitat Autònoma de Barcelona, Bellaterra, 20 I I, IO).

$5^{8}$ Se entiende que "sin [este derecho a la ejecución] la tutela de los derechos e intereses legítimos de los que obtuvieron una sentencia favorable no sería precisamente efectiva, sino que podría limitarse a conseguir declaraciones de intenciones y reconocimiento de derechos sin alcance práctico" (Calaza López, 20 i i, 22). Véase, también en este sentido, Díez-Picazo Giménez, I996, 44 ss.; Moreno Catena, V., La ejecución forzosa, cit., 27, y Moreno Catena, 200 i, I87-I89. La doctrina funda este derecho a obtener el cumplimiento efectivo de las sentencias, además, en el art. i 8 CE: "Es obligado cumplir las sentencias y demás resoluciones firmes de los Jueces y Tribunales, así como prestar la colaboración requerida por éstos en el curso del proceso y en la ejecución de lo resuelto". En este sentido, p. ej., Bermúdez Requena, J. M., “Tutela judicial efectiva y ejecución por sustitución en procesos civiles", La Ley, n. ${ }^{\circ} 6967$, Sección Doctrina, I3 de junio de 2008, año 29, ref. D-I86 (I); versión electrónica, disponible en: http:// diariolaley.laley.es/-visitado: 29/or/2016-, la que carece de numeración de páginas, por lo que las sucesivas citas a este trabajo se harán con indicación del epígrafe (en números romanos) y del sub-epígrafe (en números arábicos).

59 Así, en la sTc (Sala 2. ${ }^{a}$ ) de 18 de abril de 2005 se afirma: "[e]s doctrina constitucional reiterada que el derecho a la ejecución de Sentencias y demás resoluciones judiciales firmes constituye una manifestación del derecho a la tutela judicial efectiva, ya que en caso contrario las decisiones judiciales y los derechos que en las mismas se reconozcan o declaren serían meras declaraciones de intenciones" - (86/2005), Ponente: Magistrado D. R. Rodríguez Arribas (вов n. ${ }^{\circ}$ I 20 de 20 de mayo de 2005 ), FJ $2 .^{\circ}-$. La sTc (Sala I. ${ }^{a}$ ) de I 5 de diciembre de 1998 enumera las sentencias que asientan esta doctrina jurisprudencial: "[p]or lo que se refiere al derecho a la ejecución de las Sentencias en sus propios términos, como integrante del derecho a la tutela judicial efectiva (art. 24. I C.E.), conviene comenzar recordando la doctrina que este Tribunal tiene establecida sobre el particular. Existe una jurisprudencia reiterada (ssTc 32/1982, 6I/1984, 67/1984, I09/1984, I06/1985, I55/1985), que alcanza su punto culminante con una serie de Sentencias dictadas en 1987 (ssTc 33/1987, I25/I987, I67/1987 y 205/1987), que acabaron de perfilar la doctrina al respecto y que serán luego citadas y aplicadas en los años posteriores (ssTc I 48/I989, I 53/I992, I 94/I993, 247/I 993 y 2 I 9/I 994, entre otras)" -(240/I998), Ponente: Magistrado D. Pablo García Manzano (воE n. ${ }^{\circ}$ I 7 de 20 de enero de I999), FJ 2. ${ }^{\circ}-$.

60 stc (Sala I. $\left.{ }^{2}\right)$ de 2 I de diciembre de 1987 (205/r987), Ponente: Magistrado D. M. RodríguezPiñero y Bravo-Ferrer (вое n. ${ }^{\circ} 7$ de 8 de enero de I988), FJ $3 .^{\circ}$. 


\section{La idea de un derecho a la ejecución específica o in natura, y la idea de que esta es la vía preferente de ejecución}

[i8] ¿Permite, lo que hasta aquí se ha dicho, afirmar que existe un derecho al cumplimiento especifico de la sentencia? La respuesta no es sencilla, sobre todo si se considera el alcance que el Tribunal Constitucional ha atribuido a la garantía del art. 24. I CE:

[E]l art. 24 de la Constitución y la consagración constitucional del derecho a la tutela jurisdiccional efectiva no alcanzan a cubrir las diferentes modalidades que puede revestir la ejecución de una Sentencia, pues, supuesto que la norma constitucional se cumple si la Sentencia es efectiva y el derecho del ciudadano recibe satisfacción, hay que concluir que tan constitucional es una ejecución en la que se cumple el principio de la identidad total entre lo ejecutado y lo estatuido en el fallo como una ejecución en la que, por razones atendibles, la condena es sustituida por su equivalente pecuniario o por otro tipo de prestación ${ }^{6 \mathrm{I}}$.

La doctrina procesal desprende, en consecuencia, que "[e]l legislador ordinario tiene libertad de configuración normativa para establecer el modo de ejecución de condenas no dinerarias y, en particular, las circunstancias determinantes del cambio a una ejecución por equivalente dinerario de la prestación" ${ }^{2}$. Así pues, este derecho constitucional a la tutela judicial efectiva se satisface tanto por la ejecución in natura o específica-que es aquella que tiende a proporcionar al acreedor la satisfacción de su interés específico en la obligación ${ }^{6} 3$ - como por la ejecución sustitutiva o por equivalente (también denominada "genérica", por oposición a "específica") 64.

6r STC (Sala 2. ${ }^{a}$ ) de 29 de junio de I983 (58/ 1983), Ponente: Magistrado D. L. Díez Picazo (вое n. ${ }^{\circ}$ I 68 de 15 de julio de I983), FJ 2. ${ }^{\circ}$. Sobre el punto, véase también Magro Servet, V. (coord.), Guía práctica de la Ley de Enjuiciamiento Civil. Adaptada a la Ley 13/2009, de 3 de noviembre; Ley Orgánica I/2009, de 3 de noviembre, y Ley I9/2009, de 23 de noviembre, 4 a ed., Madrid, La Ley, 20I0, 989-990.

62 Ortells Ramos, M., "Propuesta de reforma y mejora de la ejecución no dineraria en la Ley de Enjuiciamiento Civil de 2000", en $R X G$, n. $^{\circ}$ 59, 2008, 29. En el mismo sentido, GonZÁLEZ García, M. ${ }^{a}$ Á., "Ejecución de condenas no dinerarias", en Ef, 2000 (6) 800.

63 Cfr. Antón Guijarro, J., "La ejecución provisional de resoluciones judiciales. La ejecución no dineraria", en Ef, 200 I (3) 596; y Martínez de SANtos, A., Cuestiones prácticas sobre la vía de apremio en el proceso de ejecución civil, Madrid, La Ley, $2010,7 \mathrm{I}$.

64 Esta ejecución por sustitución o por equivalente puede ser definida como "la actividad judicial ejecutiva por la que el órgano judicial ordena al ejecutado el cambio de la prestación contenida originalmente en el título ejecutivo por devenir ésta de imposible cumplimiento" (BERMúdez Requena, 2008, II.I). Así, esta vía de ejecución supone "cambiar la prestación por otra equivalente, pero distinta" (Martínez de Santos, Cuestiones prácticas, cit., 7I). 
[19] Ahora bien, pese a lo que se acaba de decir, creo que es posible afirmar que la ejecución específica o in natura sí se configura como la vía prioritaria o preferente de ejecución, por las dos siguientes razones.

i. La primera, porque el ejecutante no puede, en el momento de instar la ejecución, pedir que el ejecutado cumpla la obligación contenida en el título ejecutivo por una vía alternativa. Y es que el derecho a la ejecución de la sentencia en sus propios términos es un derecho que corresponde a todos los ciudadanos, y por tanto, no se reconoce únicamente como un derecho del ejecutante, sino también como un derecho del ejecutado ${ }^{6}$.

ii. La segunda razón es que el tribunal no tiene facultades discrecionales para elegir entre ordenar el cumplimiento específico de la sentencia y ordenar el cumplimiento de la sentencia por otras vías ${ }^{66}$.

[20] Así pues, la posibilidad de que se ordene cumplir la sentencia por una vía sustitutiva o por equivalente es algo claramente excepcional: sólo cabe en caso de que el cumplimiento en forma específica sea imposible. Así lo establece expresamente, por lo demás, el art. I 8.2 de la Ley Orgánica 6/I 985 , de I. ${ }^{\circ}$ de julio, del Poder Judicial (en adelante, LopJ) ${ }^{67}$ :

En relación con este punto, creo conveniente destacar que:

i. La imposibilidad del cumplimiento, en cuanto límite de la ejecución in natura de la sentencia, debe ser una imposibilidad producida lógicamente en una fecha posterior a la sentencia (se trata, por tanto, de una imposibilidad sobrevenida

65 Así lo ha dicho expresamente el Tribunal Constitucional: "[e]l derecho a que la Sentencia se ejecute en sus propios términos tiene un carácter objetivo en cuanto se refiere precisamente al cumplimiento del fallo sin alteración y no permite por tanto suprimir, modificar o agregar a su contenido excepciones o cargas que no puedan reputarse comprendidas en él. En consecuencia, la ejecución ha de consistir precisamente en lo establecido y previsto en el fallo y constituye, junto al derecho del favorecido a exigir su cumplimiento total e inalterado, el del condenado a que no se desvirtúe, se amplíe o se sustituya por otro. Cualquier alteración debe obedecer a causa prevista en la Ley, como lo es la imposibilidad legal o material de ejecución" -sTc 2 I9/I994, de r 8 de julio de r994, Ponente: Magistrado. D. Gabaldón López (вое n. ${ }^{\circ}$ i97 de I 8 de agosto de i 994), FJ $3 .{ }^{\circ}-$. Sobre el punto, véase Solchaga Loitegui, "Derecho a la tutela judicial efectiva y ejecución singular civil", en CDJ, I992 (IO) 25-26.

66 En este sentido, Ortells Ramos afirma que, pese a que el legislador puede organizar las vías de ejecución con libertad, "[h]a de tenerse presente, por una parte, que la efectividad del derecho a la tutela judicial quedaría decididamente anulada si la satisfacción de las pretensiones reconocidas por el fallo judicial en favor de alguna de las partes se relegara a la voluntad caprichosa de la parte condenada o, más en general, éste tuviera carácter meramente dispositivo ( $\operatorname{sTc~}_{5} 5^{/}$I $986, \mathrm{FJ} 3 .^{\circ}$ ), y, por otra parte, que ese cambio en el modo de ejecución ha de estar fundado -como dice la doctrina jurisprudencial del Tribunal Constitucional [...]- en razones atendibles" (2008, 29; las cursivas son entrecomillado en el texto original).

67 Art. i 8.2 LOPJ: "Las sentencias se ejecutarán en sus propios términos. Si la ejecución resultare imposible, el Juez o Tribunal adoptará las medidas necesarias que aseguren la mayor efectividad de la ejecutoria, y fijará en todo caso la indemnización que sea procedente en la parte en que aquélla no pueda ser objeto de cumplimiento pleno...”. 
en relación con la fecha del título ejecutivo) ${ }^{68}$. Si la imposibilidad se produce con anterioridad a la sentencia, entonces dicha imposibilidad incidirá en el contenido de la sentencia, y no en su ejecución 69.

ii. El hecho de que el cumplimiento de la sentencia por vía equivalente sea considerado una vía excepcional determina que la imposibilidad de cumplimiento deba ser acreditada, y además que sólo la imposibilidad en sentido estricto permita este cambio en la forma de ejecución ${ }^{70}$.

iii. En caso de imposibilidad de cumplimiento de la sentencia en sus propios términos, la conversión a la vía equivalente no es automática, sino que depende del ejecutante, quien debe así solicitarlo ${ }^{7 \mathrm{I}}$.

iv. Y que, por último, en la doctrina procesal se entiende que ese cumplimiento de la sentencia por la vía del cumplimiento genérico o por equivalente "no corresponde a una indemnización de daños"72.

[2 I] Todo lo que se acaba de decir, ofrece el marco general en el que se sitúan las vías por las que la LEc tiende al cumplimiento de las condenas de hacer, que son las que interesa considerar en este trabajo, y de las que se trata a continuación.

68 La imposibilidad de ejecución, que justifica la sustitución del cumplimiento específico in natura por una indemnización de daños, debe ser "sobrevenida y excepcional" -sTc de i 8 de julio de I994 (2 I9/r994), Ponente: Magistrado. D. Gabaldón López (вов n. ${ }^{\circ}$ I 97 de I 8 de agosto de I994), FJ 5.ํ-. En este sentido, véase también MAGRo SERvet (coord.), Guía práctica, cit., 990.

69 "Si en el momento de la presentación de la demanda es ya evidente que no puede procederse al cumplimiento de las obligaciones contractuales por haberse hecho imposible la misma, no se está ante el caso que ahora examinamos, pues lo procedente entonces es que se pida lo oportuno por el actor, atendida la imposibilidad, de modo que la condena de la sentencia ya debe partir de la imposibilidad [...] [C]uando la imposibilidad del cumplimiento de la obligación se produce después de la sentencia, que ha condenado de acuerdo a como de asumió la obligación, es cuando puede aparecer la imposibilidad natural de la ejecución en sus propios términos; se trata, pues, de que lo que se convierte en imposible es la ejecución de la sentencia y no ya el cumplimento de la obligación contractual": Montero Aroca, J. y Flors Matíes, J., Tratado de proceso de ejecución civil, t. 2, Valencia, Tirant lo Blanch, 2004, I 968 y 1976.

70 En este sentido, Montero Aroca y Flors Matíes, Tratado de proceso, t. 2, cit., ig68.

7 I Nadal Gómez, I., "Comentario a los arts. 699 ss. (Título v, Capítulo i)”, en Armenta, T., Cordón, F., Muerza, J. y Tapia, I. (coords.), Comentarios a la Ley de Enjuiciamiento Civil, v. 2, 2 . ' ed., Navarra, 20 i i, 637. En el mismo sentido, Fernández-Ballesteros López, La ejecución forzosa, cit., 428 .

Vigente la LEC de I88I, se entendía que la conversión a dinero (al equivalente pecuniario), en cambio, era casi automática, como explica Moreno Catena: "[e]n nuestro ordenamiento regía un mecanismo de conversión prácticamente automática de la ejecución específica por una ejecución de pago de dinero, dándole al ejecutante no aquello a lo que es acreedor, sino un equivalente pecuniario. Esta ejecución por el equivalente [...] representa el reconocimiento palmario por parte del sistema jurídico de un cierto fracaso, pues con sus propios medios, con toda la coerción que es capaz de realizar el Estado a través de los órganos judiciales, no consigue proporcionar a quien tiene derecho - porque así lo ha reconocido el propio sistema- exactamente aquello que le corresponde" (La ejecución forzosa, cit., I 24 ). 


\section{B. La ejecución específica de las condenas que imponen una obligación de hacer}

[22] Las reglas que la LEC contempla sobre ejecución de las condenas se encuentran dentro del Libro iII ("De la ejecución forzosa y de las medidas cautelares", arts. 5 I 7 ss.). Dentro de este libro se regulan de forma separada la ejecución dineraria (Tít. Iv, arts. 57 I ss.) y la ejecución no dineraria (Tít. v, arts. 699 ss.). En el marco de este trabajo interesa considerar únicamente las reglas relativas a las obligaciones no dinerarias 73 .

Ahora bien, conviene tener presente que la forma de ejecución de las obligaciones no dinerarias en la LEC no se organiza bajo un único procedimiento. Las vías de ejecución dependen de la naturaleza y del objeto de la obligación de que se trate 74 . En efecto, dentro del Título v del Libro iII, y tras un Capítulo i que contiene unas disposiciones generales (arts. 699 y 700), la ley regula, en capítulos separados, la ejecución por deberes de entregar cosas (Cap. II, arts. 70 I a 704) y la ejecución por obligaciones de hacer y no hacer (Cap. III, arts. 705 a 7I I).

De todas esas reglas sólo interesan aquí algunas de las contenidas en el Capítulo III. No interesa la ejecución de las condenas de no hacer (art. 7 Io). Tampoco interesan todas las reglas de ejecución relativas a las obligaciones de hacer. En relación con esta última delimitación, hay que considerar que la ley regula, dentro del mentado Capítulo iII del Libro iII, el procedimiento de ejecución de dos obligaciones de hacer que no consisten - $\mathrm{O}$ si se quiere, que no pueden tener su fuente- en la prestación de un servicio (a saber: la obligación consistente en publicar la sentencia en medios de comunicación - art. 707 LEC- y la condena a la emisión de una declaración de voluntad -art. 708 LEC- $)^{75}$. La atención debe centrarse, por tanto, en los arts. 705 y 7 I I, que son reglas de aplicación general

73 Es evidente que el cliente de un servicio puede obtener una condena dineraria. En este caso, el cliente del servicio (ahora ejecutante) puede lógicamente obtener el cumplimiento específico de la sentencia (esto es, obtener la suma de dinero a la que se ha condenado al ejecutado -prestador del servicio-), pero este supuesto no es el que interesa analizar. OrTELls Ramos señala que en este caso "no es dudoso que, atendida la prestación impuesta [la actividad ejecutiva adecuada es] la ejecución por obligaciones dinerarias" (Ortells Ramos, M., La ejecución de las condenas no dinerarias en la Ley de Enjuiciamiento Civil, Madrid, La Ley, 2005, 2 I I).

$74 \mathrm{Y}$ es que, como se ha puesto de relieve por algún autor, la noción de ejecución no dineraria es "puramente negativa" pues "[s]e incluye en ella toda actividad ejecutiva de ejecución forzosa distinta de la de dar una cantidad de dinero" (Carrasco García, F. Á., "Ejecución dineraria especial. Ejecución no dineraria”, en E7, 2003 (I) 867).

75 Conviene tener presente que la LEC contempla otras reglas de ejecución de las obligaciones de hacer, fuera de este Capitulo III. Como señala OrTells Ramos: "[e]l régimen de esta ejecución se completa por disposiciones aplicables a modalidades específicas de hacer. Entre ellas cabe citar las obligaciones de hacer consistentes en rendir cuenta de una administración -necesario presupuesto de la ejecución dineraria por el eventual saldo a favor del ejecutante- cuya ejecución se regula en el art. 720; y las obligaciones de hacer establecidas como medidas definitivas en las sentencias de procesos matrimoniales, a cuya ejecución se aplican como reglas especiales las del art. 776.2. ${ }^{\mathrm{a}}$ у $3 .{ }^{\mathrm{a} "}$ (La ejecución de las condenas, cit., 209). 
para la ejecución de obligaciones de hacer y no hacer; y más especialmente en los arts. 706 y 709, que regulan, respectivamente, el procedimiento de ejecución de la condena de hacer no personalísimo y de la condena de hacer personalísimo.

\section{Los aspectos generales}

[23] El art. 699.I LEC (“Despacho de la ejecución”) dispone:

Cuando el título ejecutivo contuviere condena u obligación de hacer o no hacer o de entregar cosa distinta a una cantidad de dinero, en el auto por el que se despache ejecución se requerirá al ejecutado para que dentro del plazo que el tribunal estime adecuado, cumpla en sus propios términos lo que establezca el título ejecutivo.

En el requerimiento, el tribunal podrá apercibir al ejecutado con el empleo de apremios personales o multas pecuniarias.

Lo dicho en el art. 699.I es básicamente reiterado en el art. 705 de la misma ley para las obligaciones no dinerarias ("Requerimiento y fijación de plazo"), añadiendo que ese plazo se "fijará según la naturaleza del hacer y las circunstancias que concurran" 76 .

Pues bien, lo primero que hay que apuntar es que las vías de ejecución que contemplan los arts. 706 (para las condenas de hacer no personalísimo) y 709 (para las condenas de hacer personalísimo) -que describiré de inmediato- operan sólo una vez que ha transcurrido dicho plaz 077 . Y es por ello que, desde este punto de vista, me

76 En palabras de Ortells Ramos: "[e]l art. 705 es una aplicación específica del art. 699" (La ejecución de las condenas, cit., p. 228). Aunque no se fijan plazos mínimos ni máximos, el mismo autor plantea que "tanto la letra del art. 705, como el hecho de que el modo en que deba continuar la actividad ejecutiva dependa de que el ejecutado no haya llevado a efecto el hacer en el plazo señalado [...] inducen a pensar que, en todo caso, el plazo ha de tener una duración suficiente para posibilitar el cumplimiento de la prestación por el ejecutado" (ibíd., 225).

77 El art. 706.r.I LeC indica: "Cuando el hacer a que obligue el título ejecutivo no sea personalísimo, si el ejecutado no lo llevara a cabo en el plazo señalado por el Secretario judicial, el ejecutante podrá...”; y por su parte, el art. 709.I LEC, señala: “... transcurrido este plazo [el que se haya concedido para cumplir el requerimiento a que se refiere el art. 699] sin que el ejecutado haya realizado la prestación, el ejecutante podrá...”. Ahora bien, es posible admitir que, si consta la intención del ejecutado de no realizar la conducta descrita en el título, es posible prescindir del plazo establecido en el auto que despacha la ejecución, y requerir al ejecutante para que señale la vía de ejecución por la que opta. En este sentido, el AAP de Cuenca (Sección I) de 8 de julio de 2008 (го8/2008), Ponente: Ilmo. Sr. D. A. Díaz Delgado (RJ 2. ${ }^{\circ}$ ): "Don Pedro Francisco se opuso a la ejecución contra él despachada, limitándose a señalar que era 'su intención' no ejecutar las obras, 'por lo que se pueden encargar a un tercero', ingresando la cuarta parte de lo que, a su juicio, era el importe de la obra pendiente de ejecutar. Este Tribunal no tiene objeción alguna en reconocer que al manifestarse por uno de los ejecutados la expresa voluntad de no ejecutar las obras a las que había sido condenado, puede ser prescindible esperar a que transcurra el plazo establecido en el auto despachando ejecución (en este caso dos meses). Pero, en tal 
parece posible afirmar que el sistema jurídico procesal español favorece el cumplimiento voluntario, y en sus propios términos, de la obligación que consta en el título ejecutivo. Esto por cuanto, dado que todo ejecutante debe esperar un plazo de veinte días para iniciar el procedimiento de ejecución (plazo que se cuenta desde la notificación al condenado de la sentencia, laudo o acta de mediación -art. 548 LEC $-7^{8}$ ), resulta que el plazo que otorga el tribunal en virtud de los arts. 699 y 705 es, en realidad, un segundo plazo que se concede al deudor para cumplir 79 .

[24] Sentado lo anterior, un segundo aspecto que hay que tener en consideración, antes de describir las vías de ejecución que reconocen los arts. 706 y 709, es que dichas vías de ejecución son de aplicación subsidiaria, en el sentido de que ellas sólo son aplicables en caso de que el título ejecutivo no contenga

caso, lo que debió hacerse es requerir a la parte ejecutante para que manifestase, conforme a la facultad que a él y no al ejecutado otorga el artículo 706. I de la Ley de Enjuiciamiento Civil, si optaba por encargar los trabajos a un tercero, a costa del ejecutado (valorándose previamente, en tal caso, el coste de dicho hacer por un perito tasador) o por el resarcimiento de daños y perjuicios". Por otro lado, se entiende que, una vez transcurrido el plazo, pero antes de que el ejecutante opte por las medidas de ejecución, el ejecutado puede solicitar una ampliación del plazo inicialmente concedido; cfr. Xíol Ríos (dir.), Ley de enjuiciamiento civil. Comentada, con jurisprudencia sistematizada y concordancias, $2,{ }^{\mathrm{a}}$ ed., Madrid, El Derecho, 20 10, I6 I 7.

78 Art. 548 LEC ("Plazo de espera de la ejecución de resoluciones procesales o arbitrales o de acuerdos de mediación”): "No se despachará ejecución de resoluciones procesales o arbitrales o de acuerdos de mediación, dentro de los veinte días posteriores a aquel en que la resolución de condena sea firme, o la resolución de aprobación del convenio o de firma del acuerdo haya sido notificada al ejecutado".

79 En este sentido Fernández-Ballesteros López plantea: “[1]a lec no se muestra en exceso impaciente. Concede un nuevo plazo al deudor a pesar de que éste ha tenido ya al menos dos ocasiones claras para realizar la conducta debida: cuando venció la obligación y cuando se produjo la sentencia de condena, que también contiene la orden de que se realice la prestación. A lo que se añade el plazo de gracia de 20 días que a todo condenado concede el art. 548" (La ejecución forzosa, cit., p. 414, nota 8; las cursivas son entrecomillado en el original). Se ha sostenido, por otro lado, que en el caso de las obligaciones no personalísimas, el art. 706 LEC parece conceder al ejecutado un plazo adicional a los ya mencionados. En el texto original del art. 706 se disponía que “... si el ejecutado no lo llevare a cabo en el plazo señalado por el tribunal". En su redacción actual, el art. 706. I.I LEC se refiere al plazo fijado por el secretario judicial; el artículo debe su redacción actual a la Ley ${ }_{13} / 2009$, de 3 de noviembre, de reforma de la legislación procesal para la implantación de la nueva Oficina judicial (вое n. ${ }^{\circ} 226$ de 4/I I/2009). Esto ha llevado a sostener que el art. 706 "prevé, de forma manifiestamente absurda, que el secretario judicial conceda al ejecutado un plazo para que cumpla lo ordenado en la sentencia. El legislador, en su afán de atribuir competencias al secretario judicial en la ejecución, no se ha dado cuenta de que ya el juez, al dictar el auto de despacho de la ejecución, debe señalar al ejecutado un plazo para que cumpla lo establecido en la sentencia que se trata de ejecutar. Como consecuencia del error cometido por el legislador, el ejecutado dispondrá, 'graciosamente', de dos plazos para cumplir la sentencia: a) el plazo que le fije el juez al despachar la ejecución, conforme a los arts. 699 y 705 LEC; b) y el plazo que le señale el secretario judicial, según la nueva redacción dada al art. 706 LEC por la Ley I $3 / 2009$. Cabe recordar que estos dos plazos se vienen a añadir al plazo general de espera que prevé el art. 548 Lec": Cachón Cárdenas, M., Apuntes de ejecución, cit., 93-94). Sobre la distribución de tareas entre el juez y el secretario judicial en la mentada reforma de la Lec de 2009, véase Ortells Ramos, 20 I3, i I 7-I I9. 
una regla particular para el caso del incumplimiento del ejecutado (arts. 706. I.I y $709 \cdot 4)^{80}$.

\section{Las vías de ejecución (arts. 706 y 709 LEC)}

[25] Según lo dicho, transcurridos los plazos fijados para que el condenado cumpla con la obligación sin que este haya cumplido, y siempre que el título no contenga una regla particular para el caso del incumplimiento, se aplicará lo dispuesto en el art. 706 (si el título impone un hacer no personalísimo) o lo dispuesto en el art. 709 (si el título impone un hacer personalísimo). Es de destacar que ninguno de esos artículos establece un procedimiento único de ejecución, sino que en ambos supuestos (obligación no personalísima, obligación personalísima) se reconoce al ejecutante una opción entre dos vías de ejecución ${ }^{8 \mathrm{I}}$ :

- Si la obligación de hacer es no personalísima, el ejecutante puede pedir que se le faculte para encargarlo a un tercero, a costa del ejecutado, o bien puede reclamar el resarcimiento de daños y perjuicios (art. 706.I.I) ${ }^{82}$;

80 El art. 706. I.I LEC, en relación con las obligaciones de hacer no personalísimas, indica: "Cuando el título contenga una disposición expresa para el caso de incumplimiento del deudor, se estará a lo dispuesto en aquél...". Por su parte, el art. 709.4 LEC, en relación con las obligaciones de hacer personalísimas, dispone: "No serán de aplicación las disposiciones de los anteriores apartados de este artículo cuando el título ejecutivo contenga una disposición expresa para el caso de incumplimiento del deudor. En tal caso, se estará a lo dispuesto en aquél”.

8I Que al ejecutante se conceda, en ambos supuestos, una opción, se presenta como una novedad de la LEC de 2000, en relación con la regulación de la LEC de I88I. En la Exposición de motivos de la LEC de 2000 se dice: "[m]ención especial ha de hacerse del cambio relativo a la ejecución no dineraria. Era preciso, sin duda, modificar una regulación claramente superada desde muy distintos puntos de vista. Esta Ley introduce los requerimientos y multas coercitivas dirigidas al cumplimiento de los deberes de hacer y no hacer y se aparta así considerablemente de la inmediata inclinación a la indemnización pecuniaria manifestada en la Ley de r 88 г. Sin embargo, se evitan las constricciones excesivas, buscando el equilibrio entre el interés y la justicia de la ejecución en sus propios términos, por un lado y, por otro, el respeto a la voluntad y el realismo de no empeñarse en lograr coactivamente prestaciones a las que son inherentes los rasgos personales del cumplimiento voluntario" (xvII).

82 No puede el acreedor, por tanto, pretender que se impongan multas coercitivas al ejecutado en el caso de la obligación no personalísima, pese a que del texto del art. 699.II LEC parece desprenderse que existe la posibilidad de imponer multas para todo tipo de ejecución de sentencias de hacer. Así lo entiende la doctrina y así también se ha fallado; sobre ello véase Escaler BascompTE, R., "La ejecución de sentencias no dinerarias en sus propios términos: una muestra jurisprudencial de la confusión existente. Análisis del Auto de la Audiencia Provincial de Valencia de 2 I de septiembre de 200I", en fusticia, 2004 (I-2) 379-394, y especialmente 392-394. El autor comparte el criterio de la AP de Valencia, que dejó sin efecto la multa fijada por el Juzgado de Primera Instancia, porque se trataba de una ejecución de una obligación de hacer fungible (en relación con un edificio, se había condenado a la reparación de la piedra artificial de la cubierta de todos los voladizos mediante la retirada y recolocación; y a sellar el foso del ascensor previa demolición de los revestimientos del mismo). En este aspecto, es interesante destacar que en la doctrina procesal se vincula esta regla del art. 706 con la del art. io98.i c.c. ("la regulación del art. io98.i c.c. late en el art. 706. I Lec": Fernández-Ballesteros López, La ejecución forzosa, cit., 424). 
- Si la obligación de hacer es personalísima, el ejecutante puede pedir que la ejecución siga adelante para entregar a aquel un equivalente pecuniario de la prestación de hacer; o bien puede solicitar que se apremie al ejecutado con una multa por cada mes que transcurra sin llevarlo a cabo desde la finalización del plazo (art. 709.1).

[26] En la medida en que, como puede apreciarse, las posibles vías de ejecución son distintas, según se trate de un hacer no personalísimo o un hacer personalísimo, es evidente que la calificación de la obligación que consta en el título ejecutivo es un punto muy relevante ${ }^{8}$.

En relación con ello, hay que considerar que el ejecutante, al elegir entre las vías que le confieren los arts. 706 y 709, está calificando, subjetivamente, la obligación. La pregunta es si la solicitud del ejecutante -y la calificación de la obligación que hay detrás- es vinculante para el tribunal. La respuesta depende de qué es lo que solicita el ejecutante.

En efecto, de la regulación de estos dos artículos (706 y 709) se desprende que si el ejecutante pide que se le faculte para encargar la ejecución de la obligación a un tercero, o bien solicita el resarcimiento de daños y perjuicios, la calificación de la obligación que está haciendo el ejecutante (la considera de hacer no personalísimo) sí vincula al tribunal y al ejecutado. En cambio, si el ejecutante pide que continúe la ejecución para recibir el equivalente pecuniario, o solicita que se apremie al deudor con multas (lo que implica que el ejecutante estima que la obligación consiste en un hacer personalísimo) el tribunal puede denegar esta petición, si, a su juicio, la obligación no es personalísima ${ }^{84}$. Esta solución legal -que hace vinculante la calificación de la obligación por parte del ejecutante sólo si este la considera como no personalísima - se estima coherente con principios básicos de la ejecución, en virtud de los cuales "no es legítimo forzar la libertad del

83 Y sin duda, es por ello que se reconoce al deudor la posibilidad de alegar lo que tenga por conveniente en relación con el carácter personalísimo de la obligación. Esta posibilidad se reconoce en el art. 709 LEC ("Cuando el título se refiera a un hacer personalísimo, el ejecutado podrá manifestar al tribunal, dentro del plazo que se le haya concedido para cumplir el requerimiento a que se refiere el artículo 699 [...] alegar lo que tenga por conveniente sobre el carácter personalísimo o no personalísimo de la prestación debida"). Como se puede ver, la oportunidad que tiene el ejecutado para discutir el carácter personalísimo de la obligación es anterior al momento en el que el ejecutante decide y solicita la vía de ejecución. Por tanto, es también anterior al momento en que se realizará la calificación definitiva que hace el tribunal (calificación que hace al momento de admitir o no la solicitud del ejecutante basada en alguno de los derechos que le confiere el art. 709).

$84 \mathrm{El}$ art. 706 LEC no contempla la posibilidad de que el tribunal deniegue la solicitud del ejecutante, ni tampoco admite oposición por parte del ejecutado. En cambio, el art. 709 LEc establece que si el ejecutante pretende que continúe la ejecución para recibir el equivalente pecuniario, o bien solicita que se apremie al deudor, el tribunal accederá a ello "cuando estime que la prestación que sea objeto de la condena tiene las especiales cualidades que caracterizan el hacer personalísimo. En otro caso, ordenará proseguir la ejecución con arreglo a lo dispuesto en el artículo $706 "$ " 
ejecutado más allá de lo que sea objetivamente necesario para la satisfacción del derecho del ejecutante" 85 .

Pues bien, según lo que se acaba de explicar, ante la solicitud del ejecutante por alguna de las vías que contempla el art. 709. I será el juez quien en definitiva tendrá que determinar el carácter personalísimo o no de la obligación ${ }^{86}$. El problema es que la LEC no ofrece criterios ni establece un procedimiento para tal determinación. La doctrina procesal estima que esos criterios hay que extraerlos de los conceptos indeterminados de "hacer personalísimo" y de "hacer no personalísimo" ${ }^{8}$. Para precisar tales conceptos suele recurrirse al derecho sustantivo (p. ej., al art. I i6I c.c. $)^{88}$. Una forma muy común de explicar la diferencia es que el hacer debe considerarse fungible "cuando puede ser realizado por una persona distinta del deudor con el mismo contenido e idénticos resultados; de no ser así, la conducta es infungible" ${ }^{89}$. Para el caso particular de las obligaciones de hacer derivadas de con-

85 En este sentido, Ortells Ramos entiende que "estas soluciones legales -de vinculación y de no vinculación, respectivamente, para el hacer no personalísimo y personalísimo- son coherentes con principios básicos de ejecución [...] [ya que] no es legítimo forzar la libertad del ejecutado más allá de lo que sea objetivamente necesario para la satisfacción del derecho del ejecutante[...] [S]i el ejecutante estima que su derecho queda satisfecho con la actuación de un tercero a costa del ejecutado, está justificado que la ley confiera a esa apreciación eficacia vinculante de la decisión del tribunal, porque de este modo se puede alcanzar el fin de la ejecución -la satisfacción del ejecutante (art. 570)- sin limitar la libertad personal del ejecutado, sino afectando solamente su patrimonio.

"Si por el contrario, el ejecutante estima imprescindible el hacer personal del ejecutado, el juez ha de tener plena potestad de decisión, para ponderar concretamente las exigencias de la tutela de la libertad personal y las del derecho a la tutela judicial efectiva, como derecho a que el fallo se cumpla" (Ortells Ramos, La ejecución de las condenas, cit., 237).

Y más adelante reitera que "a esta apreciación del ejecutante sólo le da la ley una relevancia decisiva, si concluye en que el hacer es no personalísimo e insta su realización a costa del ejecutado. Su instancia es, entonces, vinculante para el tribunal" (ibíd., 243).

86 En este sentido, Moreno Catena, La ejecución forzosa, cit., I3 I.

87 Según Ortells Ramos, "[p]ara realizar esta determinación son normalmente necesarios un criterio de fondo y una cierta actividad procesal para aplicarlo al asunto concreto. El criterio de calificación no lo define la ley, sino que hay que extraerlo de los conceptos jurídicos indeterminados de hacer no personalísimo y personalísimo. Por otro lado, las oportunidades (y la necesidad) de que el tribunal aplique estos criterios se hallan muy acotadas por el modo en que el ejecutante ejercite las posibilidades procesales que le conceden los arts. 706 y 709. Algún procedimiento, propiamente dicho, para la aplicación de los criterios, tampoco está previsto por la LEC" (La ejecución de las condenas, cit., 233].

88 En este sentido, por ejemplo, Moreno Catena: "En el concepto de lo que sea personalísimo, el artículo ir6i c.c. alude a que 'se hubiesen tenido en cuenta la calidad y circunstancias del deudor al establecer la obligación y no se encontrara persona idónea para ello'. Pues bien, de este precepto se debe extraer una doble premisa: la primera, de carácter subjetivo, que llevó al acreedor a considerar al obligado como el sujeto especialmente adecuado para realizar la prestación; la segunda, con claros tintes objetivos, que no permite sustituir al deudor por otra persona que cumpla en condiciones similares" (La ejecución forzosa, cit., I30).

89 González García, 2000, 8I3. Más adelante, la autora sugiere que el "carácter personalísimo o no de la prestación no se puede determinar atendiendo a criterios apriorísticos, sino que depende fundamentalmente del interés del acreedor, y de que éste haya establecido la obligación en razón de las circunstancias personales del deudor" (ibíd., 823). En términos similares 
tratos se ha sugerido que, a la hora de determinar si la obligación es fungible o no fungible, no sólo debe mirarse la voluntad de las partes, sino que también hay que considerar "la relación como se presenta en su significado objetivo (valor social y económico)"9o.

\section{3. ¿Hay en la LEC elementos que determinen en alguna medida la elección del ejecutante por una particular vía de ejecución?}

[27] Como se ha dicho, ya se trate de obligaciones de hacer no personalísimo, ya se trate de obligaciones de hacer personalísimo, el ejecutante tiene una opción entre dos vías de ejecución. Y es él quien, en cada caso, elige cuál de las dos vías que le ofrece la LEC satisface mejor su derecho. Esto quiere decir que, una vez establecido el carácter personalísimo o no de la obligación, ni el tribunal ni el ejecutado pueden oponerse a la vía de ejecución elegida por el ejecutante. La decisión viene determinada, por tanto, por la voluntad del ejecutante.

Siendo esto así, y a modo de conclusión de este apartado sobre el derecho al cumplimiento específico desde la perspectiva procesal, creo oportuno preguntarse si existe algún elemento en la regulación legal que pueda influir en la decisión del ejecutante. Me referiré, en primer lugar, a la elección entre la autorización para que ejecute un tercero y el resarcimiento de daños, en las obligaciones de hacer no personalísimo. Luego, me referiré al caso de las obligaciones personalísimas.

[28] Tratándose de las obligaciones de hacer no personalísimas, el art. 706, como ya se ha dicho, otorga al acreedor una opción entre encargar el hacer a un tercero y el resarcimiento de daños.

¿Es la ejecución por tercero una vía de ejecución atractiva para el ejecutante? Para responder, conviene destacar que si "el ejecutante optare por encargar el hacer a un tercero, se valorará previamente el coste de dicho hacer por un perito tasador

FERnÁndez-Ballesteros López, quien señala, a modo de ejemplo, que "es fungible la conducta que consiste en reparar un coche, pintar las paredes de un edifico o construir una valla de protección a lo largo de una carretera" (La ejecución forzosa, cit., 423). Y más adelante expresa que "infungible es una conducta que, porque se pactó fundamentalmente en consideración de las cualidades de la persona del obligado, no puede ser realizada por persona distinta del deudor con el mismo contenido y con idénticos resultados" (ibíd., 426).

90 Cfr. Ortells Ramos, La ejecución de las condenas, 243. Agrega el mismo autor que, por otro lado, "hay casos en los que la prestación podría ser realizada por otro, con la misma utilidad para el ejecutante, por persona distinta del ejecutado [...] pero que en concreto, sólo puede ser cumplida por el ejecutado, dado que éste dispone de los medios técnicos imprescindibles para llevar a cabo la prestación que requiere el ejecutado.

“[...] [a] mi juicio, si la causa de estar limitada al ejecutado la posibilidad de realizar la prestación, es de carácter jurídico - por ejemplo: monopolio de derecho, necesidad de utilizar, para la realización del hacer, un procedimiento patentado del que el ejecutado es licenciatario exclusivo-, el hacer debe considerarse personalísimo" (ibíd., 245). 
designado por el Secretario judicial" (art. 706) ${ }^{91}$. Tras ello, el ejecutado debe depositar la cantidad aprobada, o afianzar el pago. En caso de que no haga ni lo uno ni lo otro, se procederá de inmediato al embargo de bienes y a su realización forzosa hasta obtener la suma que sea necesaria ${ }^{2}$.

El problema es que del texto del art. 706 no queda claro si dicha suma -la valoración del coste de la prestación- tiene el carácter de suma liberatoria para el deudor o si debe considerarse como una suma aseguradora de su solvencia93. Creo que tal falta de claridad puede operar como un desincentivo para el ejecutante, en relación con la opción por la ejecución por tercero como vía de ejecución. Ello, puesto que podría ocurrir que el ejecutante encargase a un tercero la ejecución 94 sin saber si tiene totalmente cubierto, o afianzado, el importe que deberá pagar al tercero. $\mathrm{Y}$ es que hay que considerar que esta vía de ejecución, aun cuando los tribunales la han denominado como "ejecución in natura por tercero"95, supone una nueva

9I El art. 706 LEC nada dice sobre la posibilidad de recusar al perito, o de objetar el informe. EsCALER BASCOMPTE muestra que el punto no es pacífico en los tribunales: mientras que algunos se han decantado por una interpretación literal del texto del artículo, denegando la posibilidad de las partes de plantear alegaciones al respecto, otros tribunales admiten tales alegaciones, en protección de las garantías procesales. Escaler Bascompte es de esta segunda opinión (Escaler Bascompte, R., "Diferentes interpretaciones. Preceptos lec. Ámbito de la cuestión: ejecución condenas no dinerarias", en fusticia, 2007 (3-4), I 83-185). En esta segunda línea se ha afirmado que debe entenderse que plantear estas alegaciones es posible, ya que "cualquier otra situación vulnera y quebranta los derechos de defensa y contradicción” -cfr. Xiol Ríos (dir.), ob. cit., I634-. En todo caso, hay que tener presente que el decreto que apruebe el monto es "susceptible de recurso directo de revisión sin efecto suspensivo ante el Tribunal que dictó la orden general de ejecución" (art. 706.2 LEC).

92 Lógicamente, puede que se haya trabado embargo de bienes del deudor con anterioridad, en virtud de un embargo preventivo, como una medida cautelar (arts. 72 I ss. LEC).

93 "También debemos tomar en consideración, como recogen muchas sentencias de las Audiencias Provinciales, la parquedad de la regulación que establece la Ley de Enjuiciamiento Civil cuando se trata del cumplimiento de obligaciones de hacer no personalísimo y el ejecutado se niega a su ejecución, optando el ejecutante por encargar la ejecución a un tercero, al amparo del artículo 706-2 de la Ley de Enjuiciamiento Civil, puesto que no es pacífica la jurisprudencia sobre la posibilidad de aplicar un trámite de rendición de liquidación y comprobación posterior, así como tampoco si la cantidad fijada inicialmente por el juzgador, tras la pericial, tiene el carácter de entrega liberatoria para el deudor o aseguratoria de su solvencia y, por tanto, cabe una liquidación final en la que se pueda incluir el incremento del coste de la reparación": AAP Valencia (Sección 7) de ro de abril de 2007 (6/2007), Ponente: Ilma. Sra. M. ${ }^{a}$ del C. Escrig Orenga (FJ $3{ }^{\circ}$ ).

94 "La nueva Ley deja claro que el encargo lo bará directamente el ejecutante (previamente autorizado por el Ejecutor -706 i y 2), lo que significa que corresponde al ejecutante elegir al tercero que realizará la prestación”: Fernández-Ballesteros López, La ejecución forzosa, cit., 424; cursivas del original.

95 Así por ejemplo, el AAP Barcelona (Sección I 3) de 2 de septiembre de 2004: en este caso, el tribunal calificó la obligación impuesta al demandado en la sentencia -obligación consistente en "retirar cajas, conducciones eléctricas, cableados y conexiones [...] reponiendo la fachada [de la casa del demandante] a su estado anterior"- como una obligación de hacer no personalísima ("o insustituible", dice el tribunal), y entiende que en tal caso, el ejecutante, si opta por que la obligación se ejecute a costa del ejecutado, opta por una ejecución in natura por tercero -(4039/2004), Ponente: no se indica (RJ 2. $\left.{ }^{\circ}\right)$-. 
y distinta relación contractual entre el ejecutante y el tercero, y por tanto, el ejecutante es quien debe pagar al tercer $0^{96}$.

Si bien, como se acaba de indicar, el art. 706 no lo deja claro, se ha entendido que esa suma -la valoración del coste de la prestación- ha de considerarse "como anticipo y garantía de las sumas necesarias para la ejecución, sometido a posterior control o liquidación judicial, es decir, si la obra cuesta más de lo indicado por el perito, el ejecutante podrá reclamar el exceso" 97 . Y, por tanto, desde este punto de vista, podría sugerirse -creo- que la vía de ejecución "por tercero" representa teóricamente una ventaja en relación con la alternativa de solicitar el resarcimiento de los perjuicios, en el caso de que el ejecutante esté pensando en obtener la prestación de un tercero en un momento posterior. Esto, porque una vez firme la resolución que fija la suma indemnizatoria esta no podrá ser modificada ${ }^{8}$.

[29] Tratándose de obligaciones de hacer personalísimo, el art. 709 LEc, como ya se ha dicho, ofrece al acreedor una elección entre la imposición de multas coercitivas o que la ejecución continúe para obtener el equivalente pecuniario de la prestación.

La introducción de las multas coercitivas en el proceso civil español -institución desconocida por la LEC de I88 I ${ }^{[99]}$ - se consideró, desde un comienzo, como una de las principales novedades de la LEC de $2000^{[\mathrm{Ioo}]}$.

96 Ortells Ramos señala los argumentos para concluir esto: básicamente, que en ningún lugar de la LEC se regula ningún aspecto vinculado al contrato con el tercero, y que no hay ningún requisito ni procedimiento para la selección del tercero (La ejecución de las condenas, cit., 249). Véase también, sobre este punto, Fernández-Ballesteros López, La ejecución forzosa, cit., 425.

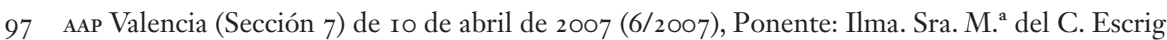
Orenga $\left(\mathrm{FJ} 4 .^{\circ}\right)$.

98 La opción por el resarcimiento de los daños requiere cuantificarlos, lo que se hace de conformidad con las reglas contenidas en los arts. 7 I 2 ss. LEc. Básicamente, se trata de un procedimiento contradictorio: el ejecutante solicita la indemnización, acompañando una relación de los daños y su valoración, pudiendo acompañar dictámenes y documentos que considere oportuno (art. 7 I3.I); de todo ello se da traslado al ejecutado, por diez días. Si el ejecutado está conforme (art. 7I4.I), o transcurre dicho plazo sin oposición, o el ejecutado simplemente se limita a negar genéricamente la existencia de daños y perjuicios, sin concretar los puntos en que discrepa, se entiende que está conforme con la relación del ejecutante (art. 7I4.2); "se hará efectiva la suma convenida en la forma establecida en los artículos 57 I y siguientes para la ejecución dineraria" (art. 7 I4.I). Si el ejecutado se opone motivadamente, se sustanciará la liquidación de los daños y perjuicios en vista, siendo posible el nombramiento de perito para que dictamine sobre la liquidación. El tribunal por medio de auto dentro de los cinco días siguientes a la vista, fijará la suma que deba abonarse al acreedor como daños y perjuicios (art. 7 I 6.I LEC).

99 En este sentido, “[l] as respuestas que da[ba] la Ley de enjuiciamiento de $\mathrm{I} 88 \mathrm{I}$, frente a la actitud renuente del obligado es [era] muy limitada; se centra[ba], bien en ordenar que se haga a su costa (como en el hacer no personalísimo), bien en una indemnización de daños, en caso de hacer personalísimo. A diferencia de lo que sucedía en otros ordenamientos, en donde se regulaba medios indirectos encaminados a domar la voluntad del ejecutado, en el nuestro sólo se preveía la opción por daños y perjuicios, o el hacer a su costa que, al final, se traducía en una valoración económica del hacer" (SÁnchez Rivera, P., "La ejecución no pecuniaria en la nueva Ley de Enjuiciamiento Civil (Ley I/2000)", en Ef, 2000 (6) 774). Y como afirma Escaler Bascompte, el reconocimiento de un derecho a la ejecución in natura en la Constitución de I978 no modificó 
Las multas coercitivas se consideran una medida indirecta de apremio, de naturaleza procesal, no penal ${ }^{\text {ror }}$, y cuya finalidad es "evitar [...] que la 'resistencia pasiva' del ejecutado -o su recta oposición- hagan imposible la satisfacción 'in natura' del derecho del acreedor ejecutante contenido en el título ejecutivo. Con el empleo de 'apremios personales' y de 'multas pecuniarias' o 'coercitivas' pretende el Legislador colocar al ejecutado en una posición jurídico-económica en la que le resulte 'más rentable' cumplir la condena impuesta que atenerse a las consecuencias de su incumplimiento" ${ }^{\text {Io2. }}$.

Ahora bien, ¿es la imposición de multas una vía de ejecución atractiva para el ejecutante? Me parece evidente que la respuesta depende de la efectividad que tenga el régimen de multas para obtener que el deudor cumpla con la obligación, y que cumpla lo más pronto posible. Y en este sentido, tanto la cuantía como la duración de las multas son factores que me parecen importantes.

En relación con la cuantía de las multas, el art. 7 I I LEc dispone que "el tribunal [...] tendrá en cuenta el precio o la contraprestación del hacer personalísimo

esta situación, ya que "el Tribunal Supremo abogando por una interpretación literal de los arts. 924-925 LEC I 88 I, ha sido flexible a la hora de permitir la ejecución por sustitución, siendo muy reacio a la adopción de medidas coercitivas para doblegar la voluntad del ejecutado. Afortunadamente, había alguna excepción. Quizás la única relevante se halle en el requerimiento de cumplimiento bajo apercibimiento de incurrir en delito de desobediencia del art. $556 \mathrm{CP}$ o la falta del art. $6_{34} \mathrm{CP}$, la cual sí que halló más comúnmente muestras de aceptación tanto a nivel jurisprudencial como doctrinal” (Escaler Bascompte, 2004, 382). En el mismo sentido, véase Fernández-Ballesteros López, La ejecución forzosa, cit., 4I3-4I 4 y nota 7.

ioo En este sentido, entre otros: González García, 2000, 82 5 ; Pérez del Blanco, G., "La incorporación de la técnica de la astreinte al proceso civil español: las multas coercitivas en la Ley de enjuiciamiento civil", en CEFLegal, n. ${ }^{\circ}$ 46, 2004 (9) 4I; y Vegas Torres, 2000, I6I. Conviene destacar que fuera de la LEC hay otros casos en los que el derecho español reconoce la figura de las multas coercitivas. Para una enumeración de esos otros casos - materia que excede el ámbito de nuestro estudio- véase Ortells Ramos, M., “¿Multas o astricciones?: una indefinición de la

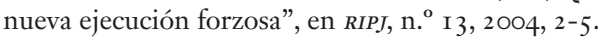

io I Como explica Ortells Ramos: "[e]n términos generales, los medios de coerción indirecta pueden ser de naturaleza penal -específica tipificación como delitos de las determinadas conductas o posibilidad de subsumirlas en los tipos de desobediencia a la autoridad- o de naturaleza procesal, consistentes en la imposición por el juez de la ejecución de deberes de pago de sumas de dinero con el fin de estimular la voluntad de cumplimiento del ejecutado.

"En mi opinión, los medios coercitivos de la segunda clase son más adecuados que los de naturaleza penal. En primer lugar, porque las multas coercitivas o las astricciones -por no prejuzgar aspectos de su régimen jurídico que veremos después- resultan cualitativamente proporcionados, porque afectan a derechos de naturaleza patrimonial, como los que, por regla general, constituyen objeto de la litigiosidad civil. En segundo lugar, porque son más coherentes con el sistema jurídico que la amenaza de sanción penal, e, incluso, más efectivos que ésta.

"Lo primero (la coherencia), porque respetan el principio de intervención penal mínima. Lo segundo (la mayor efectividad), porque, presupuesto un cierto activo patrimonial y una suficiente transparencia del patrimonio sujeto, es más real e inmediata la potestad coercitiva del mismo juez de la ejecución que trasladar el tanto de culpa a la jurisdicción penal” (2013, I2 I).

IO2 AAP de Tarragona (Sección I) de I I de noviembre de 2005 (663/2005), Ponente: Ilmo. Sr. D. J. L. Portugal Sainz (RJ 3..$^{\circ}$ ); igual en el aAp Madrid (Sección Io) de r..$^{\circ}$ de julio de 2009 (9883/2009), Ponente: Ilmo. Sr. D. A. M. Illescas Rus (FJ $4 .^{\circ}$ ). 
establecidos en el título ejecutivo y, si no constara en él o se tratara de deshacer lo mal hecho, el coste dinerario que en el mercado se atribuya a esas conductas. / Las multas mensuales podrán ascender a un 20 por Ioo del precio o valor..." I03.

Como puede apreciarse, de ello resulta que, si en un caso determinado se fija la multa mensual en el máximo permitido por la ley (el 20\% del valor de la prestación), el ejecutado (prestador del servicio) se verá económicamente conminado a ejecutar la obligación antes de que se le imponga la quinta multa mensual, porque en tal caso ha debido pagar, por vía de multa, una suma que alcanzará al І $00 \%$ del valor de la prestación debida.

En relación con la duración de las multas hay que considerar que esta vía de ejecución cuenta con una limitación temporal. El art. 709.3 LEC establece:

Cuando se acuerde apremiar al ejecutado con multas mensuales, se reiterarán trimestralmente por el Secretario judicial responsable de la ejecución los requerimientos, hasta que se cumpla un año desde el primero.

Si, al cabo del año, el ejecutado continuare rehusando hacer lo que dispusiese el título, proseguirá la ejecución para entregar al ejecutante un equivalente pecuniario de la prestación o para la adopción de cualesquiera otras medidas que resulten idóneas para la satisfacción del ejecutante y que, a petición de éste y oído el ejecutado, podrá acordar el Tribunal.

Que las multas tengan un plazo máximo implica que, pese a la opción del ejecutante por la vía de las multas, el proceso de ejecución podría terminar, igualmente, en una ejecución por el equivalente pecuniario ${ }^{104}$. Hay que tener presente que la posibilidad de que, a esta altura (es decir, transcurrido el año en el que se han aplicado las multas), se impongan al ejecutado otro tipo de medidas que resulten idóneas (posibilidad que reconoce el mentado art. 709.3) no es un derecho del

IO3 Estos aspectos relativos a la determinación de la cuantía de las multas diferencian a la multa coercitiva de la LEC de la astreinte francesa, pese a que se trata de medidas de apremio similares. $\mathrm{Al}$ contrario de la multa coercitiva, la astreinte no es una suma fija e invariable, sino que puede ir en aumento en el tiempo frente a la resistencia del ejecutado, y además puede ser revisada, disminuyéndose, o dejada sin efecto; cfr. Pérez del Blanco, 2004, 48-49.

IO4 El establecimiento del límite del año ha sido criticado por Escaler BAScompte, en estos términos: "[a]nte la dificultad de articular otras fórmulas de apremio que puedan tener mayor eficacia para asegurar el cumplimiento en sus términos, no se comprende por qué el legislador corta la posibilidad de seguir coercionando por esta vía transcurrido el año. Más aun cuando el propio legislador, en otros puntos de la LEC, como al regular la ejecución forzosa para los procesos matrimoniales en el art. $776 \mathrm{LEC}$, no ha tenido inconveniente en reconocer el mantenimiento de las multas coercitivas por todo el tiempo que haga falta en caso de incumplimiento de las obligaciones no pecuniarias de carácter personal" (2008, 277). 
ejecutante, sino que se trata de medidas de apremio que dependen de la discrecionalidad del tribunal ${ }^{\text {Io5. }}$.

La posibilidad de que el ejecutante deba, transcurrido el año, conformarse, finalmente, con el equivalente pecuniario de la prestación, es un aspecto que el ejecutante habrá de tener en consideración a la hora de optar por la vía de las multas. Y es que, además del tiempo invertido en tratar de obtener la prestación, la suma en que consiste la multa coercitiva no beneficia al ejecutante, sino al Estado ${ }^{\mathrm{10}}$. Y, por esta razón, la merma del patrimonio del ejecutado, que se produce a través de la vía de las multas coercitivas, podría significar un riesgo para la satisfacción del crédito del ejecutante, en el caso en que, finalmente, no quede más remedio que buscar la satisfacción por la vía del equivalente pecuniario ${ }^{107}$.

\section{Conclusiones}

En este trabajo se ha comenzado por afirmar que la pregunta por el derecho del cliente de un servicio al cumplimiento específico puede y debe ser analizada desde dos perspectivas distintas. Una perspectiva de análisis es la del derecho al cumplimiento específico desde el punto de vista del derecho sustantivo, esto es, el derecho del acreedor a obtener una condena de cumplimiento especifico. La otra pers-

IO5 "Es el juez quien decide sobre la conveniencia o no de acordarlas": Pardo Iranzo, V., Ejecución de sentencias por obligaciones de hacer y de no hacer, Tirant lo Blanch, 200 I, 3 I I. Por otro lado, no es claro qué medidas podrían imponerse. Según Escaler Bascompte, una medida de apremio podría ser el ser el apercibimiento de incurrir en delito de desobediencia (2008, 277). En el mismo sentido Fernández-Ballesteros, quien precisa que entre esas medidas cabe "la amenaza expresa de sanción penal por el delito de desobediencia", aunque luego explica que "la doctrina penalista no es partidaria de aplicar este tipo, y otra serie de sentencias del TS así lo ha confirmado" (La ejecución forzosa, cit., 427 y nota 47). En términos parecidos Moreno Catena, 2OOI, I97-I98.

Io6 Aunque en la LEC no se establece expresamente que las multas sean en beneficio del erario público, así lo entiende la doctrina (cfr., p. ej., Pérez del Blanco, 2004, 49, y FernándezBallesteros López, La ejecución forzosa, cit., p. 428). Como muestra Sánchez Rivera, el hecho de que la multa coercitiva beneficia al Estado, y no al ejecutante, la distingue de otras figuras afines, como son las indemnizaciones coercitivas que contemplan la Ley I7/200I, de Marcas (воЕ n. ${ }^{\circ} 294$ de 8/I2/200I), art. 44 ("Indemnizaciones coercitivas"), y la Ley 20/2003, de Protección jurídica del Diseño Industrial (вое n. ${ }^{\circ}$ I 62 de 8/7/2003), art. 55 ("Cálculo de los daños y perjuicios e indemnizaciones coercitivas") (cfr. SÁNChez Rivera, P., "Las indemnizaciones coercitivas", en La Ley, n. ${ }^{\circ}$ 7919, Sección Doctrina, ref. 8236/201 2, en particular para un estudio sobre la naturaleza y características de las mentadas indemnizaciones coercitivas).

IO7 En este sentido Ortells Ramos, sobre todo, porque es posible plantear que la multa establecida en beneficio del erario público tenga preferencia desde el punto de vista de la prelación de los créditos, frente al derecho del ejecutante al equivalente pecuniario (2OI3, I 22). En este punto, entiende Fernández-Ballesteros López que "lo razonable sería conferir preferencia en todo caso a la ejecución de la indemnización de daños y perjuicios para el ejecutante: porque aunque multas coercitivas y daños y perjuicios sean partidas independientes, lo cierto es que las primeras están al servicio de la satisfacción del interés del ejecutante [...] y no es razonable que, algo previsto para beneficiarle, pueda tornarse en perjuicio suyo" (La ejecución forzosa, cit., 428 , nota 50 ). 
pectiva de análisis -que además desde el punto de vista del proceso se plantea en un momento posterior- es la perspectiva procesal, esto es, el derecho al cumplimiento específico de la condena a un hacer. Finalizado el estudio, las principales conclusiones que surgen del mismo son las siguientes:

I. En lo que respecta a la perspectiva sustantiva:

a) En el derecho español, el acreedor puede demandar al deudor el cumplimiento específico de la obligación debida, pero ello no quiere decir que vaya a obtener una condena favorable. La posibilidad de obtener una condena al cumplimiento específico de la obligación tiene dos límites claros. Uno, que sea todavía posible el cumplimiento de la obligación en los términos pactados. El otro, que la demanda de cumplimiento específico respete las exigencias de la buena fe (art. 7 c.c.). Además de esos dos límites (que pueden ser interpretados de manera más o menos amplia) la doctrina moderna considera la razonabilidad de introducir algunos otros. Es lógico que, en la misma medida que la procedencia de la pretensión de cumplimiento se limite, más fácil resulte poner en tela de juicio la idea de que el acreedor tiene derecho al cumplimiento específico, así como la idea de que este sea el remedio preferente.

b) Lo anterior, que se dice de forma general respecto de cualquier clase de obligación, es también cierto en relación con las obligaciones de hacer. En este sentido, el art. ro98 c.c., el cual es el único que se refiere al efecto de las obligaciones de hacer, no dice nada en relación con la posibilidad de obtener que se condene al propio deudor al cumplimiento específico. Ello es así porque se entiende que este artículo contiene una norma de carácter procesal, que opera en la fase de ejecución, y que por tanto presupone esa condena al cumplimiento específico. Por la misma razón, el hecho de que la Lec contemple, o no, vías de apremio para obtener el cumplimiento en forma específica, tampoco incide en la posibilidad de obtener una condena en contra del deudor al cumplimiento específico de la obligación contractual de hacer.

2. En lo que respecta a la perspectiva procesal, el estudio permite concluir que:

a) El cliente de un servicio, que haya obtenido a su favor una sentencia en la que se condena al prestador del servicio a realizar la prestación de hacer en la que consiste el servicio (condena de cumplimiento específico), puede obtener una satisfacción in natura. ¿Qué significa esto? Si se trata de una obligación consistente en un hacer no personalísimo, ello significa que, ante la negativa o pasividad del deudor, es posible encargar la prestación a un tercero, a cargo del ejecutado (deudor). El ejecutante obtiene así la prestación debida, pero de persona distinta del deudor. En este caso no existe la posibilidad de imponer apremios al condenado, a fin de obtener que este cumpla por sí mismo. Si, en cambio, se trata de una obligación consistente en un hacer personalísimo, el ejecutante puede solicitar que se apremie con multas al ejecutado, para buscar que este cumpla con la sentencia en sus propios términos. No obstante, estas multas pueden extenderse sólo por un año. 
b) Si bien se admite que el derecho constitucional a la tutela judicial efectiva se satisface teóricamente tanto por la vía del cumplimiento in natura como por la vía del cumplimiento por equivalente, creo que es posible afirmar que en el ordenamiento jurídico-procesal español existe cierta preferencia por la ejecución in natura. Por un lado, porque la vía sustitutiva se considera excepcional: opera sólo en caso de imposibilidad de la ejecución in natura. Por otro lado, porque esa preferencia por la vía del cumplimiento específico se manifiesta en los sucesivos plazos que se le conceden al condenado para cumplir con la obligación. Sólo una vez que transcurren esos sucesivos plazos se admite que sea el ejecutante quien decida la vía que, a esa altura del proceso, le parezca más conveniente: si insiste en obtener el cumplimiento de la obligación, o bien si quiere obtener del deudor una suma de dinero (a título de indemnización o de equivalente pecuniario).

\section{Bibliografía}

Abella Rubio, J. M. a "Efectos del incumplimiento”, en O’Callaghan Muñoz, X. (coord.) Cumplimiento e incumplimiento del contrato, Madrid, Editorial Universitaria Ramón Areces, 201 2, 361-382.

Antón Guijarro, J., "La ejecución provisional de resoluciones judiciales. La ejecución no dineraria”, en E7, 200 I (3) 53 I-606.

Alonso Rodríguez, M. a Á., "Ejecución. Presupuestos y disposiciones generales. Ejecución provisional", en EF, 2003 (I), 753-799.

Ayllón Santiago, H., "Cumplimiento sensu stricto en contrato unilateral y en contrato bilateral”, en O’Callaghan Muñoz, X. (coord.) Cumplimiento e incumplimiento del contrato, Madrid, Editorial Universitaria Ramón Areces, 2OI 2, 23-I 30 .

Badosa Coll, F., "Comentario del art. ro98”, en Paz-Ares et al. (dirs.) Comentario del Código Civil, Madrid, Ministerio de Justicia, I993, t. 2, 28-30.

Bermúdez Requena, J. M., "Tutela judicial efectiva y ejecución por sustitución en procesos civiles”, en Diario La Ley, n. 6967 (Sección Doctrina), I 3 Jun. 2008, año 29, Ref. D-ı 86, disponible en: http://diariolaley.laley.es/ [consultado el 29 de enero de 2016$]$.

Cachón Cárdenas, M., Apuntes de ejecución procesal civil, Universitat Autònoma de Barcelona, Bellaterra, 20 I . 
Calaza López, S., "Principales proyecciones del Derecho a la tutela judicial efectiva en la doctrina del Tribunal Constitucional”, en RGDP, n. 23, 20 I I.

Carrasco García, F. Á., "Ejecución dineraria especial. Ejecución no dineraria”, en $E 7,2003$ (I), 867-910.

Carrasco Perera, Á., Derecho de contratos, Aranzadi, 20 io.

Carrasco Perera, Á., "Reparación en forma específica y reparación a costa del deudor en la responsabilidad por ruina", en Indret I/2006.

De Diego y Gutiérrez, F. C., Instituciones de Derecho Civil Español, nueva edición revisada y puesta al día por Alfonso De Cossio y Corral y Antonio GuLlón Ballesteros, Madrid, I959 (t. 2).

Díez-Picazo Giménez, I., "Artículo 24: garantías procesales”, en Alzaga VillaAmIL, O. (dir.), Comentarios a la Constitución Española de I978, t. 3, Madrid, Edersa, I996, I9-1 24.

Díez-Picazo y Ponce de León, L., Fundamentos del Derecho civil patrimonial, Civitas, Madrid, t. II [(Las relaciones obligatorias) 6. ${ }^{\mathrm{a}}$ ed., 2008] y t. IV [(Las particulares relaciones obligatorias) I. ${ }^{\mathrm{a}}$ ed., $\left.20 \mathrm{I0}\right]$.

Domínguez Luelmo, A., "Incumplimiento y ejecución forzosa en forma específica de las obligaciones de hacer", en Llamas Ромво, E. (coord.), Estudios de derecho de obligaciones de obligaciones: homenaje al profesor Mariano Alonso Pérez, Madrid, La Ley, 2006, 557-586.

Escaler Bascompte, R., "Diferentes interpretaciones. Preceptos lec. Ámbito de la cuestión: ejecución condenas no dinerarias", en fusticia, 2007 (3-4), I $83-185$.

Escaler Bascompte, R., "La ejecución de sentencias no dinerarias en sus propios términos: una muestra jurisprudencial de la confusión existente. Análisis del Auto de la Audiencia Provincial de Valencia de 2 I de septiembre de 200I", en Fusticia, 2004 (I-2), 379-394.

Escaler Bascompte, R., "Prevalencia del derecho a la ejecución en sus propios términos con respecto a los posibles límites en cuanto a la tipología de medidas ejecutivas y a la duración de la ejecución”, en fusticia. Revista de Derecho procesal, 2008 (3-4), 255-293. 
Esteban De la Rosa, G. y Gómez Valenzuela, E., "La acción de cumplimiento específico en la contratación internacional", en Sánchez Lorenzo, S. (coord.), Derecho contractual comparado: una perspectiva europea y transnacional, Civitas, Navarra, 2013, I 597-I644.

Fenoy Picón, N., El sistema de protección del comprador, Madrid, Colegio de Registradores de la Propiedad y Mercantiles de España, 2006.

Fenoy Picón, N., "La modernización del régimen del incumplimiento del contrato: propuestas de la Comisión General de Codificación. Parte segunda: los remedios del incumplimiento", en $A D C$, n. 64, 20 I I (4), I 48 I- I684.

Fernández-Ballesteros López, M. Á., La ejecución forzosa y las medidas cautelares, Madrid, Irgium, $200 \mathrm{I}$.

Gómez Calle, E., "Los remedios ante el incumplimiento del contrato: Análisis de la Propuesta de Modernización del Código Civil en materia de obligaciones y contratos y comparación con el Borrador del Marco común de referencia", en $A D C$, n. $^{\circ}$ 65. 2012 (I), 29-IO2.

Gómez Pomar, F., "El incumplimiento contractual en Derecho Español”, en Indret 3/2007.

González García, M. a Á., "Ejecución de condenas no dinerarias”, en EF, 2000 (6), 799-828.

Jordano Fraga, F., "Las reglas generales de la responsabilidad contractual en el sistema del Código Civil español", en ADC, I985, 275-399.

Ledesma Martínez, M. J., Las obligaciones de hacer, Granada, Comares, I 999.

Llamas Ромво, E., Cumplimiento por equivalente y resarcimiento del daño al acreedor. Entre la estimatio rei y el id quod interest, Madrid, Trivium, I999.

Magro Servet, V. (coord.), Guía práctica de la Ley de Enjuiciamiento Civil. Adaptada a la Ley I3/2009 y LO I/2009, 4. ${ }^{\mathrm{a}}$ ed., Madrid, La Ley, 20 IO.

Manresa y Navarro, J. M., Comentarios al Código Civil Español por D. Fosé Maria Manresa y Navarro con la colaboración de varios jurisconsultos y una introducción del Excmo. Sr. D. Francisco de Cárdenas, Madrid, t. 8 [(1907; $2^{\text {a }}$ ed.)] . 
Manrique De Lara Morales, J., "La ejecución forzosa de la obligación de hacer infungible", en $A D C$, n. 54, 200 I (3), I I65-I 224.

Marsal Guillamet, J. y Lauroba Lacasa, M. ${ }^{a}$ E., "Algunos mecanismos de protección en caso de incumplimiento contractual en un futuro derecho europeo de contratos: cumplimiento específico e indemnización por daños y prejuicios", en Cabanillas, A. (coord.), Estudios jurídicos en homenaje al profesor Luis Díez-Picazo, v. 2, Civitas, 2002, 2455-2470.

Martín Pérez, A., "Comentario del artículo iog8”, en Albadalejo, M. (dir.) Comentarios al Código Civil y compilaciones forales, t. I 5, v. I, Madrid, Edersa, I $978,326-34$ I.

Martínez de Aguirre Aldaz, C. (coord.) Curso de Derecho civil II. Derecho de Obligaciones, $3 .^{\mathrm{a}}$ ed., Madrid, Colex, $20 \mathrm{I}$ I.

Martínez de SAntos, A., Cuestiones prácticas sobre la vía de apremio en el proceso de ejecución civil, Madrid, La Ley, 20 Io.

Montero Aroca, J. y Flors Matíes, J., Tratado de Proceso de ejecución civil, Valencia, Tirant lo Blanch, 2004.

Morales Moreno, A. M., "Claves de la modernización del Derecho de Contratos", en Consejo General del Notariado, Autonomía de la voluntad en el Derecho privado. Estudios en conmemoración del 150 aniversario de la Ley del Notariado, t. III-I, Wolters Kluwer, 20 I 2, 3 I 8-430.

Morales Moreno, A. M., La modernización del Derecho de Obligaciones, Navarra, Thomson-Civitas Aranzadi, 2006.

Moreno Catena, V., "Algunos problemas de la ejecución forzosa", en aFdUaM, n. 5, 200I, I87-200.

Moreno Catena, V., La ejecución forzosa [t. 4 de Cortés Domínguez, V./Moreno Catena, V. (coords.) La nueva Ley de enjuiciamiento civil], Madrid, Tecnos, 2000.

Moreno Quesada, B, "Problemática de las obligaciones de hacer", en RDP, n. 60, I $976,470-502$.

Ortells Ramos, M., La ejecución de las condenas no dinerarias en la Ley de Enjuiciamiento Civil, Madrid, La Ley, 2005. 
Ortells Ramos, M., "La ejecución forzosa civil. Tres cuestiones sobre qué ejecutar, quién puede o debe hacerlo y cómo”, en RDUM, n. 22, 2013, IO9-I 25.

Ortells Ramos, M., “¿Multas o astricciones?: una indefinición de la nueva ejecución forzosa”, en RIPJ, n. I 3, 2004.

Ortells Ramos, M., "Propuesta de reforma y mejora de la ejecución no dineraria en la Ley de Enjuiciamiento Civil de 2000”, en $R X G$, n. 59, 2008, 29-58.

Pantaleón Prieto, F., "El sistema de responsabilidad contractual (materiales para un debate)", en $A D C$, n. 44, I991, Iог9-го9 I.

Pantaleón Prieto, F., "Las nuevas bases de la responsabilidad contractual”, en $A D C$, n. 46, I993, I 7 I9-I 746.

Pardo Iranzo, V., Ejecución de sentencias por obligaciones de hacer y de no bacer, Tirant lo Blanch, 200I.

Pérez del Blanco, G., "La incorporación de la técnica de la astreinte al proceso civil español: las multas coercitivas en la ley de enjuiciamiento civil", en $C E-$ FLegal, n. ${ }^{\circ}$ 6, 2004 (9), 39-64.

Pinto Ruiz, J., "Estudio sobre el artículo i 24 del Código Civil”, en arajL, n. ${ }^{\circ}$ 4I, 201 I, 259-562.

Sánchez Castro, J. D., "El cumplimiento por equivalente: ¿un modo de evitar los requisitos imprescindibles en toda pretensión indemnizatoria?”, en $A D C$, n. ${ }^{\circ} 63,2010(4)$, I 725-I 787.

Sánchez Rivera, P., "La ejecución no pecuniaria en la nueva Ley de Enjuiciamiento Civil (Ley I/200o), en Ef, 2000 (6), 773-798.

SÁnchez Rivera, P., "Las indemnizaciones coercitivas", en Diario La Ley, n. o 7919, Sección Doctrina, ref. 8236/201 2.

Santos Briz, J., "Comentario del artículo iog8”, en Sierra Gil de la Cuesta, I. (coord.) Comentario del Código Civil, Bosch, t. 6, 2. ${ }^{\mathrm{a}}$ ed., Barcelona, Bosch, 2006, I 23 - I 28 .

Scaevola, Q. M., Comentarios al Código Civil, Madrid, i893-i91 5, t. i 9 y t. 24. 
Severin Fuster, Gonzalo, "El derecho al cumplimiento específico de la obligación de hacer en la doctrina española del siglo xIX anterior a la codificación civil", Revista de Estudios Histórico-furídicos, n. 37, 201 5, 377-397.

Solchaga Loitegui, "Derecho a la tutela judicial efectiva y ejecución singular civil”, en CDJ, n. Io, 1992 (Ejecución de sentencias civiles), I3-46.

Vattier Fuenzalida, C., "Notas sobre el incumplimiento y la responsabilidad contractual”, en Redur, 3, 2005, 57-68.

Vegas Torres, J., "Ejecución forzosa y medidas cautelares en la nueva Ley de enjuiciamiento civil”, en Icade, n. 50, 2000 (mayo-agosto), I43-I62.

Verdera Server, R., "Comentario del artículo iog8”, en Cañuzares, A., De Pablo, P., Orduña, J. y Valpuesta, R., (dirs.), Código Civil comentado, v. 3, Navarra, Thomson-Civitas Aranzadi, 20 I I, I 289-I 29 I.

Verdera Server, R., El cumplimiento forzoso de las obligaciones, Bolonia, Publicaciones del Real Colegio de España, I995.

Xíol Ríos, J. A. (dir.), Ley de enjuiciamiento civil. Comentada, con jurisprudencia sistematizada y concordancias, 2. ${ }^{\mathrm{a}}$ ed., Madrid, El Derecho, 20 Iо.

\section{Resoluciones judiciales citadas}

STs (Sala I. ${ }^{a}$ ) del I7 de mayo de 1957 (Repertorio de jurisprudencia I957/2 I64) Ponente Excmo. Sr. D. F. Eyré Varela.

STc (Sala 2. ${ }^{a}$ ) del 29 de junio de 1983 (58/1983) Ponente: Magistrado D. L. Díez Picazo.

Stc (Sala I. $\left.{ }^{a}\right)$ del 2 I de diciembre de I987 (205/1987) Ponente: Magistrado D. M. Rodríguez-Piñero y Bravo-Ferrer.

Sts (Sala I. ${ }^{2}$ ) del I 2 de diciembre de 1990 (9I40/I990) Ponente: Excmo. Sr. D. P. González Poveda.

stc (Sala r. ${ }^{a}$ ) del I7 de octubre de r99I (194/r99r) Ponente: Magistrado D. F. García-Mon y González-Regueral.

stc de 18 del julio de 1994 (2 19/1994) Ponente: Magistrado. D. Gabaldón López. 
sts (Sala r. ${ }^{a}$ ) del 2 de Julio de 1998 (4434/1998) Ponente: Excmo. Sr. D. I. Sierra Gil de la Cuesta.

Stc (Sala I. ${ }^{a}$ ) del I5 de diciembre de I998 (240/1998) Ponente: Magistrado D. Pablo García Manzano.

Sts (Sala r. ${ }^{a}$ ) del 28 de Junio de 1999 (4583/r999) Ponente: Excmo. Sr. D. X. O’Callaghan Muñoz.

sts (Sala r. ${ }^{a}$ ) del 3 de abril de 2000 (2730/2000) Ponente. Excmo. Sr. J. E Corbal Fernández.

ats del 6 de Febrero de 200I (223 I/200I) Ponente: Excmo. Sr. D. J. Almagro Nosete.

Sts (Sala I. ${ }^{a}$ ) del 30 de abril de 2002 (3107/2002) Ponente: Excmo. Sr. D. J. Corbal Fernández.

sts (Sala I. $\left.{ }^{a}\right)$ del 7 de mayo de 2002 (320I/2002) Ponente: Excmo. Sr. D. A. Romero Lorenzo.

Sts (Sala r. ${ }^{a}$ ) del ro de marzo de 2004 (I653/2004) Ponente: Excmo. Sr. D. A. Villagómez Rodil.

AAP Barcelona (Sección I3) del 2 de septiembre de 2004 [(4039/2004) Ponente: no se indica.

STC (Sala 2. ${ }^{a}$ ) del I 8 de abril de 2005 (86/2005) Ponente: Magistrado D. R. Rodríguez Arribas.

Sts (Sala r. ${ }^{a}$ ) del I3 de Julio de 2005 (4759/2005) Ponente: Excma. Sra. Dña. E. Roca Trías.

AAP de Tarragona (Sección I) del i I de noviembre de 2005 (663/2005) Ponente: Ilmo. Sr. D. J. L. Portugal Sainz.

SAP de Tarragona (Sección I) del I8 de octubre de 2006 (I493/2006) Ponente: Ilmo. Sr. D. J. L. Portugal Sainz.

AAP Valencia (Sección 7) del io de abril de 2007 (6/2007) Ponente: Ilma. Sra. M. ${ }^{a}$ del C. Escrig Orenga. 
sts (Sala I. ${ }^{a}$ ) del 27 de Julio de 2007 (7775/2007) Ponente: Excmo. Sr. D. J. Almagro Nosete.

SAP de Salamanca (Sección I) del i 8 de diciembre de 2007 (634/2007) Ponente: Ilmo. Sr. D. I. García del Pozo.

AAP de Cuenca (Sección I) del 8 de Julio de 2008 (I08/2008) Ponente: Ilmo. Sr. D. A. Díaz Delgado.

SAP de Pamplona/Iruña (Sección I) del I 7 de febrero de 2008 (5 I $7 / 2008$ ) Ponente: Ilmo. Sr. D. F. Poncela García.

aAp Madrid (Sección Io) del I de Julio de 2009 (9883/2009) Ponente: Ilmo. Sr. D. A. M. Illescas Rus.

SAP de Madrid (Sección Io) del I 8 de noviembre de 2010 (I $7624 / 20$ Io) Ponente: Ilmo. Sr. D. Á.V. Illescas Rus. 